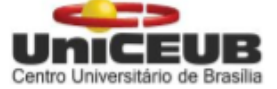

CENTRO UNIVERSITÁRIO DE BRASÍLIA - UniCEUB FACULDADE DE TECNOLOGIA E CIÊNCIAS SOCIAIS APLICADAS

PROGRAMA DE INICIAÇÃO CIENTÍFICA
\end{abstract}

ISABELLE BRAZ AMARILIO DA CUNHA

ESTUDO DE ADEQUAÇÃO DOS ESPAÇOS ABERTOS INTERNOS DO UNICEUB

BRASÍLIA-DF

2017

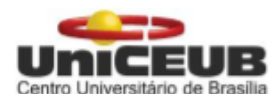




\section{ESTUDO DE ADEQUAÇÃO DOS ESPAÇOS ABERTOS INTERNOS DO UNICEUB}

Relatório final do Programa Institucional de Bolsas de Iniciação Científica e Tecnológica apresentado à Assessoria de Graduação e Pesquisa pela Faculdade de Tecnologia e Ciências Sociais Aplicadas - FATECS

Orientação: Prof. ${ }^{\text {a }}$ Dra. Ana Paula Borba Gonçalves Barros

\section{BRASÍLIA-DF}

2017 


\section{DEDICATÓRIA}

À todos os estudantes, funcionários e professores

do Centro Universitário de Brasília. 


\section{AGRADECIMENTOS}

À minha família pelo apoio incondicional, pelo amor e cuidado que sempre tiveram.

Ao Lucas Oliveira pelo companheirismo, carinho e atenção, além da colaboração e orientações que me inspiraram diariamente.

À minha orientadora Ana Paula Borba pela dedicação e paciência em ensinar que me levaram a cultivar um grande amor pelo urbanismo e pela pesquisa.

Ao professor Raphael Matos pelo incentivo de aprofundar em diferentes campos da pesquisa e o auxílio durante o processo.

À Ana Cláudia Bazzo pela parceria, amizade e ajuda em toda a pesquisa.

Ao grupo Pés Urbanos e todos os colaboradores pelo conhecimento compartilhado.

Aos participantes dos grupos focais, pela confiança e auxílio que proporcionaram ótimos resultados à esta pesquisa.

Aos colegas Carolina Rocha, Carolina Ros, Carolina Stuart, Hugo Rafael, Júlia Pereira, Maria Cristina Farago, Raquel Albuquerque, Talita Hoshino, Victória Ghillioni, Victória Webster pela amizade e pela ajuda durante a aplicação dos questionários.

Aos professores, amigos e colegas do curso de Arquitetura e Urbanismo.

Ao UniCEUB e CNPq pelo incentivo à pesquisa. 


\title{
ESTUDO DE ADEQUAÇÃO DOS ESPAÇOS ABERTOS INTERNOS DO UNICEUB
}

\author{
Isabelle Braz Amarilio da Cunha - UniCEUB, PIBIC Institucional, aluna \\ bolsista, isabellebraz17@gmail.com
}

Ana Paula Borba Gonçalves Barros - UniCEUB, professora orientadora

ana.barros@uniceub.br

\begin{abstract}
Resumo
Este trabalho de Pesquisa de Iniciação Científica é resultado da investigação e análise da utilização dos espaços abertos internos do Centro Universitário de Brasília, no qual foi realizado um estudo quali-quanti (que utiliza métodos de pesquisas qualitativas e quantitativas) baseado em três etapas: Grupo Focal 1, Grupo Focal 2 e aplicação de 300 questionários, respectivamente. Na primeira etapa (grupo focal 1), o moderador guiou um grupo de sete funcionários da instituição a construírem um dado dialogado de forma coletiva, com o objetivo de estudar e entender as visões dos entrevistados. Na segunda etapa (grupo focal 2), o mesmo procedimento metodológico foi realizado com nove estudantes da universidade, com o objetivo de comparar os pontos de vista do primeiro com o segundo grupo, cada reação foi observada e registrada para melhor análise. Por fim, a terceira etapa compreende a análise dos Grupos Focais e elaboração de perguntas destinadas à aplicação de trezentos questionários, a fim de abranger uma amostra maior para o estudo.

Ao longo das três etapas, verificou-se grande insatisfação por parte de alunos e funcionários relacionadas tanto aos espaços abertos, quanto aos fechados, indicando um problema maior do que o imaginado inicialmente. A discussão aponta que há falta de espaços de qualidade para descansar, estudar e comer, fazendo a maioria das pessoas utilizar soluções práticas para suprirem as necessidades enfrentadas diariamente, bem como frequentar lugares externos entre os intervalos das aulas, voltar para casa, descansar na casa de colegas que moram próximos à universidade, ou, até mesmo, passar o tempo dentro dos veículos. Assim, utilizam de meios improvisados na tentativa de garantir o bem-estar durante a jornada de trabalho e estudo.
\end{abstract}

Conclui-se, portanto, que há a necessidade de utilizar de melhor forma os espaços fornecidos pela universidade. Primeiramente, utilizando as "zonas mortas" (como estacionamentos e áreas vazias) para instalar mobiliários, arborização a fim de atender as necessidades dos estudantes e funcionários da instituição. Segundo, incentivando os estudantes a se deslocarem para o Centro Universitário de Brasília por meio de caronas solidárias ou de transportes limpos, como a bicicleta, disponibilizando bicicletários em todo 0 campus. Terceiro, criando políticas de incentivo à permanência na universidade por mais tempo com o intuito de diminuir o uso de transporte de veículos poluidores (veículos individuais motorizados) e incentivar a integração entre os alunos, os funcionários e a universidade.

Palavras-chaves: Universidade, estacionamentos, espaços de convivência, modernismo, Brasília. 


\section{SUMÁRIO}

1. Introdução

2. Referencial Teórico

2.1 Mobilidade e cidades

2.1.1 O modernismo e a mobilidade das cidades

2.1.2 Cidades as pessoas

2.2 Espaços Urbanos

2.2.1. As funções da Rua

\subsubsection{UNIVER(CIDADE)}

3. Metodologia

3.1 Pesquisa quali-quanti

3.2. Grupo Focal

3.3 Contagem de pessoas por meio de fotos

3.4 Coleta de dados a partir da aplicação do questionário

4. Análise dos resultados

4.1 Grupo Focal 1

4.2. Grupo Focal 2

4.3 Grupo de palavras

4.4 Contagem de pessoas por meio de fotos

4.5 Questionários

5. Considerações finais

5.1 Conclusões

5.2 Recomendações

6. Anexo I 


\section{LISTAS DE FIGURAS}

Figura 1: Desenho das tesourinhas "Flor de Brasília".

Figura 2: Representação gráfica.

Figura 3: Modelo de um Grupo Focal.

Figura 4: Mapa do UniCEUB, numeração de blocos.

Figura 5: Mapeamento dos estacionamentos ao redor do UniCEUB.

Figura 6: Conjunto de palavras mais citadas no Grupo Focal 1, com funcionários.

Figura 7: Conjunto de palavras mais citadas no Grupo Focal 2, com estudantes.

Figura 8: Áreas escolhidas para a contagem de fotos.

Figura 9: Ponto 1.

Figura 10: Ponto 2.

Figura 11: Ponto 3.

Figura 12: Ponto 4.

Figura 13: Ponto 5

Figura 14: Ponto 6.

Figura 15: Ponto 4.

Figura 16: Ponto 8.

Figura 17: Ponto 9.

Figura 18: Ponto 9.

Figura 19: Ponto 10.

Figura 20: Ponto 10.

Figura 21: Ponto 10.

Figura 22: Ponto 11.

Figura 23: Estacionamentos internos.

Figura 24: Pedestres precisam desviar dos carros.

Figura 25: Estacionamento é meio de acesso aos blocos.

Figura 26: Pedestre em Brasília.

Figura 27: Pedestre em uma instituição particular.

\section{LISTA DE TABELAS}

Tabela 1: Exemplos de justificativas da questão dissertativa do questionário.

\section{LISTA DE GRÁFICOS}

Gráfico 1: Questão doze do questionário cruzada com o local de moradia. Gráfico 2: Questão doze do questionário cruzada com o meio de transporte. Gráfico 3: Questão treze do questionário cruzada com o local de moradia. Gráfico 4: Questão treze do questionário cruzada com o meio de transporte. Gráfico 5: Questão quinze do questionário cruzada com o local de moradia. Gráfico 6: Questão quinze do questionário cruzada com o meio de transporte. Gráfico 7: Questão dezesseis do questionário cruzada com o local de moradia. Gráfico 8: Questão dezesseis do questionário cruzada com o meio de transporte. 


\section{INTRODUÇÃO}

O modernismo teve forte impacto na forma de deslocamento e na interação entre pessoas ao longo do tempo e, ainda hoje, colhem-se os frutos oriundos de cidades como Brasília, berço do urbanismo racionalista, os espaços ditados pelo seu planejamento afetaram o modo de vida da sociedade, os meios de transporte e até nas relações sociais.

Cabe ressaltar, que a forte influência do modernismo, em Brasília, fomentou o frequente uso do automóvel como principal meio de deslocamento, visto que a cidade possui grandes distâncias e carece de transporte público eficiente. Isto afetou também o desempenho de espaços particulares, como universidades, que se viram cada vez mais coagidos a receber a população de carro, tendo que criar inúmeros estacionamentos para atender a demanda de pessoas que desaguam diariamente no estabelecimento e arredores.

É sob este prisma que este trabalho visa apresentar os resultados de um estudo realizado no Centro Universitário de Brasília (UniCEUB), localizado em uma área nobre da cidade, na 707/907 da Asa Norte. Com base na metodologia quali-quanti utilizada, a pesquisa teve como principal objetivo fazer um estudo sobre os impactos de um planejamento modernista nos espaços abertos internos da universidade, a fim de analisar as consequências decorrentes da cidade em que está inserida. 


\section{REFERENCIAL TEÓRICO}

\subsection{Mobilidade e cidades}

\subsubsection{O Modernismo e a mobilidade das cidades}

O conceito de Cidade Funcional estabelecido por Le Corbusier publicado na Carta de Atenas (CORBUSIER, 1933), na década de 30, teve o intuito de solucionar os problemas decorrentes do aumento da população urbana, para isso, a cidade precisou ser vista sob um olhar funcional e ser tratada como uma máquina, assim, os arquitetos e urbanistas da época acreditaram que 0 desenvolvimento vertical aliado à existência de grandes áreas verdes tornariam a cidade mais limpa e higiênica com grandes espaços abertos e funcionais.

O modernismo proporcionou a criação de grandes obras públicas, como a de pontes e estradas e, consequentemente, o desenvolvimento de extensas malhas viárias que gerou o afastamento das moradias dos centros urbanos e resultou no uso excessivo do automóvel como principal meio de transporte, alterando completamente o ritmo urbano, uma vez que abriu espaço nas avenidas para os carros e deixou os pedestres à margem do descaso, com pequenas calçadas.

No Brasil, um dos acontecimentos que levaram a teoria urbanística modernista ser concretizada foi o planejamento urbano de Brasília (LEME, 1999), cuja vertente visava o rápido desenvolvimento da cidade, priorizando grandes edifícios e rodovias em altas velocidades. Estas mudanças urbanas foram marcadas por uma era avanço do transporte e da tecnologia, criando novos referenciais relacionados à moradia, transporte e trabalho, resultando em um período conhecido pela crescente presença do automóvel no cotidiano da população.

O projeto da capital foi feito visto de cima, característica que exibe o contraste entre as áreas verdes e a típica "Flor de Brasília" (SPECK, 2012); o trevo de concreto (Figura 1). No entanto, segundo Gehl, a cidade é uma catástrofe ao nível dos olhos, visto que a escala humana fica à parte do planejamento urbano, resultando em grandes áreas largas e amorfas que desagradam 0 pedestre, forçando-os a criar estratégias para caminhar em uma cidade com um rígido desenho urbano, deixando marcas no solo que ressaltam o protesto dos pés e os caminhos de desejo das pessoas (Destaque Figura 1). 


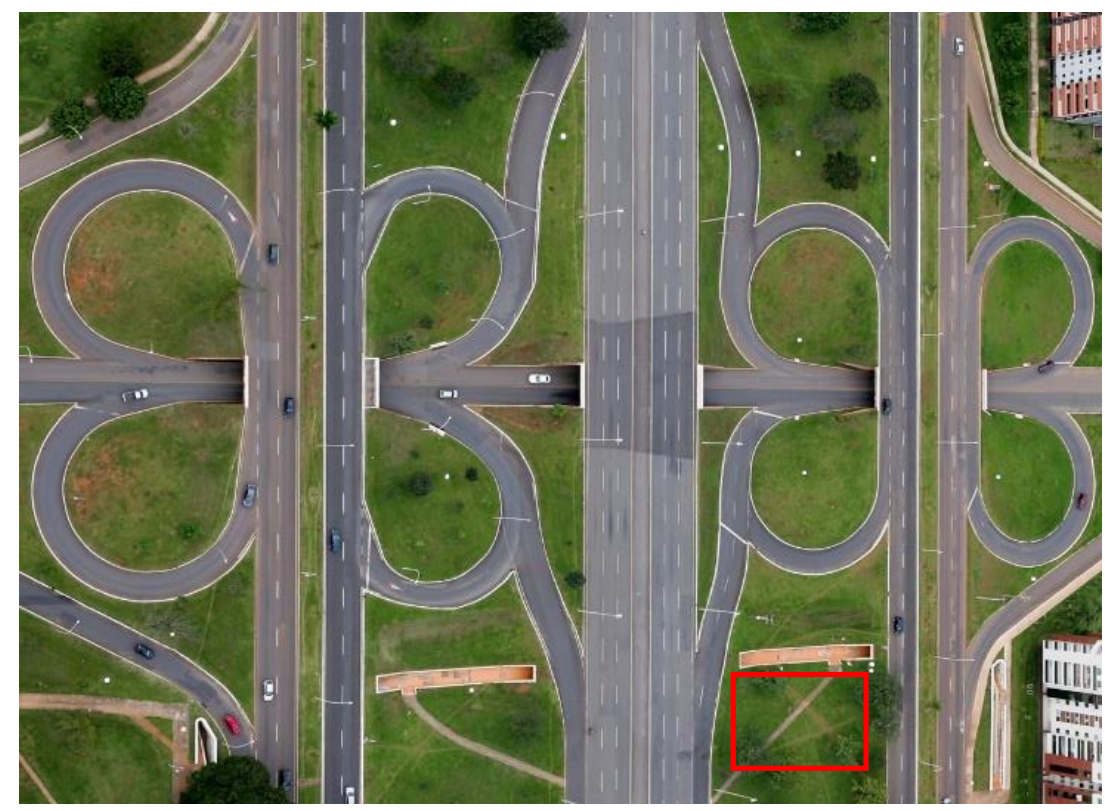

Figura 1: Desenho das tesourinhas "Flor de Brasília" do Plano Piloto que dão acesso ao Eixão e aos eixinhos nortes, nas quadras 14. Destaque em vermelho dos caminhos de desejo dos pedestres.

Fonte: http://internacional.estadao.com.br/blogs/olhar-sobre-omundo/brasilia-50-anos/

A inserção do automóvel no cotidiano dos cidadãos brasilenses afetou muito além do estilo de vida das pessoas, pois o carro tornou-se uma extensão do ambiente doméstico e, dessa forma, começaram a atribuir valor, status e luxo aos donos, resultado de uma projeção narcisista da sociedade (BAUDRILLARD,1989). Portanto, em Brasília, o uso dos automóveis não ocorre apenas por necessidade, ele invade outras esferas que correspondem desde a autovalorização do sujeito até a visibilidade econômica.

A consequência da supervalorização do carro juntamente com grandes distâncias e um fraco sistema de transporte urbano, ocasionou no problema da cidade; um trânsito caótico e a necessidade de inúmeros estacionamentos para atender a enorme demanda de veículos que desagua no Plano Piloto diariamente.

Atualmente, segundo avaliação da Engenharia do Departamento de Trânsito do Distrito Federal (Detran-DF) existem cerca de 20.000 vagas regulamentadas disponíveis na Região Administrativa de Brasília, fora a quantidade estacionamentos irregulares, uma vez que não existem dados concretos para determinar a área que ocupam, mas pode-se afirmar que inúmeros hectares foram abertos no tecido urbano para abrigar estas máquinas. Como se não fosse suficiente, a população de Brasília clama por mais estacionamentos e 
pedem projetos que planejam a criação de mais de vagas, com objetivo de solucionar o problema da alta demanda, no entanto, nesse contexto o DetranDF afirmou:

\begin{abstract}
"Apesar do anseio da população por mais estacionamentos, especialistas garantem que essa solução é paliativa e sempre estará aquém do crescimento da frota. $E$ no $D F, o$ número de veículos aumenta $8 \%$ ao ano, em média. Atualmente existem 1.127.260 registrados no Detran. De acordo com o chefe da Engenharia do órgão, Joel Rodrigues, desses, cerca de 600 mil circulam por dia em todo o DF. Os demais ficam estacionados. ". Fonte: Correio Braziliense, 2009.
\end{abstract}

Infelizmente, a resolução deste problema crônico de mobilidade urbana não se resume ao aumento do número de vagas, pois se fosse uma solução, milhares de cidades não continuariam tendo o mesmo problema após aumentarem os estacionamentos da cidade. Segundo Speck, um estudo feito em 1998 pelo Projeto de Políticas Públicas para Transporte de Superfície, durante quinze anos, setenta áreas metropolitanas foram estudadas a fundo e concluíram que:

\begin{abstract}
"Áreas metropolitanas que investiram pesadamente em expansão da capacidade viária não se saíram melhor na diminuição do congestionamento do que áreas metropolitanas que não 0 fizeram.”. (SPECK, 2012).
\end{abstract}

O resultado da pesquisa mencionada engloba o número de vagas destinadas aos estacionamentos, visto que a demanda dos motoristas tende a preencher a disponibilidade, ou seja, é uma equação equivalente e proporcional, pois quanto mais espaço para carros houver, mais veículos, mais tráfego haverá. 0 estacionamento amplo encoraja as pessoas a dirigirem mais, e exemplifica que requisitos de estacionamento fora da rua são como uma droga de fertilidade para os carros (SPECK, 2012).

Donald Shoup, engenheiro e economista, analisa em seu livro, The High Cost of Free Parking (2004), os estacionamentos sob a ótica econômica para entender qual o valor que custam e quem paga por eles, pois a gratuidade de inúmeros estacionamentos não pode ser associada com pouco custo. $O$ autor demonstrou em suas pesquisas que muitas cidades lidam de forma errada com o tema e em vez de o estacionamento trabalhar a serviço da cidade, as 
cidades, quase sempre em prejuízo próprio, têm trabalhado a serviço deles. (SHOUP, 2004).

\subsubsection{Cidades para pessoas}

Brasília foi planejada para uma sociedade em um período específico da história e, como todos os experimentos, algumas coisas deram certo e outras não, porém, o ser humano e a sociedade sofrem constantes mudanças ao longo dos anos e a cidade precisa se adequar conforme essas mudanças. Para isso, cabe aos arquitetos e urbanistas corrigirem os problemas atuais em prol dessa nova sociedade, mas ao mesmo tempo devem respeitar as ideias iniciais da cidade.

As preocupações com a melhoria do espaço urbano vêm se tornando um assunto cada vez mais frequente nas cidades do século XXI, sendo notório que a ideia de cidades vivas, seguras, sustentáveis e saudáveis, além de um desejo, é uma necessidade universal (GEHL, 2010).

À vista disso, cabe apontar que a geração $Y$ (pessoas nascidas entre 19801990), conhecida por ser formada por cidadãos criativos que preferem comunidades com ruas vibrantes e cheias de vida, já a geração $Z$ (pessoas nascidas entre 1990-2010), vem abdicando dos automóveis e tem se mostrado mais interessada em utilizar outros meios de transporte e ter uma vida saudável, e a caminhabilidade é apontada como um quesito cada vez mais desejado (SPECK, 2012).

O ser humano foi feito para viver em comunidade, de acordo com uma declaração de Hávamál, poeta irlandês, o homem é a alegria do homem, pois é nas relações sociais que as experiências se tornam intensas, portanto trabalhar com a escala humana é criar bons espaços urbanos ao nível dos olhos, é nas cidades que os contatos sociais são feitos e na interação que se encontra a riqueza e a vitalidade pública (GEHL, 2010).

Segundo as ideias de Jacobs (1961), é ideal que haja diversidade para uma cidade ser viva, segura, sustentável e saudável (GEHL, 2010), as áreas urbanas necessitam de usos mistos para proporcionar diferentes experiências para os cidadãos e garantir caminhabilidade para estimular além das atividades necessárias (Figura 2), pois quando o planejamento urbano visa criar espaços de alta qualidade, as atividades sociais e opcionais também aumentam, conforme Gehl (2010) afirma no fragmento abaixo:

"As cidades devem propiciar boas condições para que as pessoas caminhem. Parem, sentem-se, olhem, ouçam e falem. Se tais atividades básicas, ligadas aos sentidos e ao aparelho motor humano puderem ocorrer em boas condições, essas e outras atividades relacionadas deverão ser capazes de se desdobrar em todas 


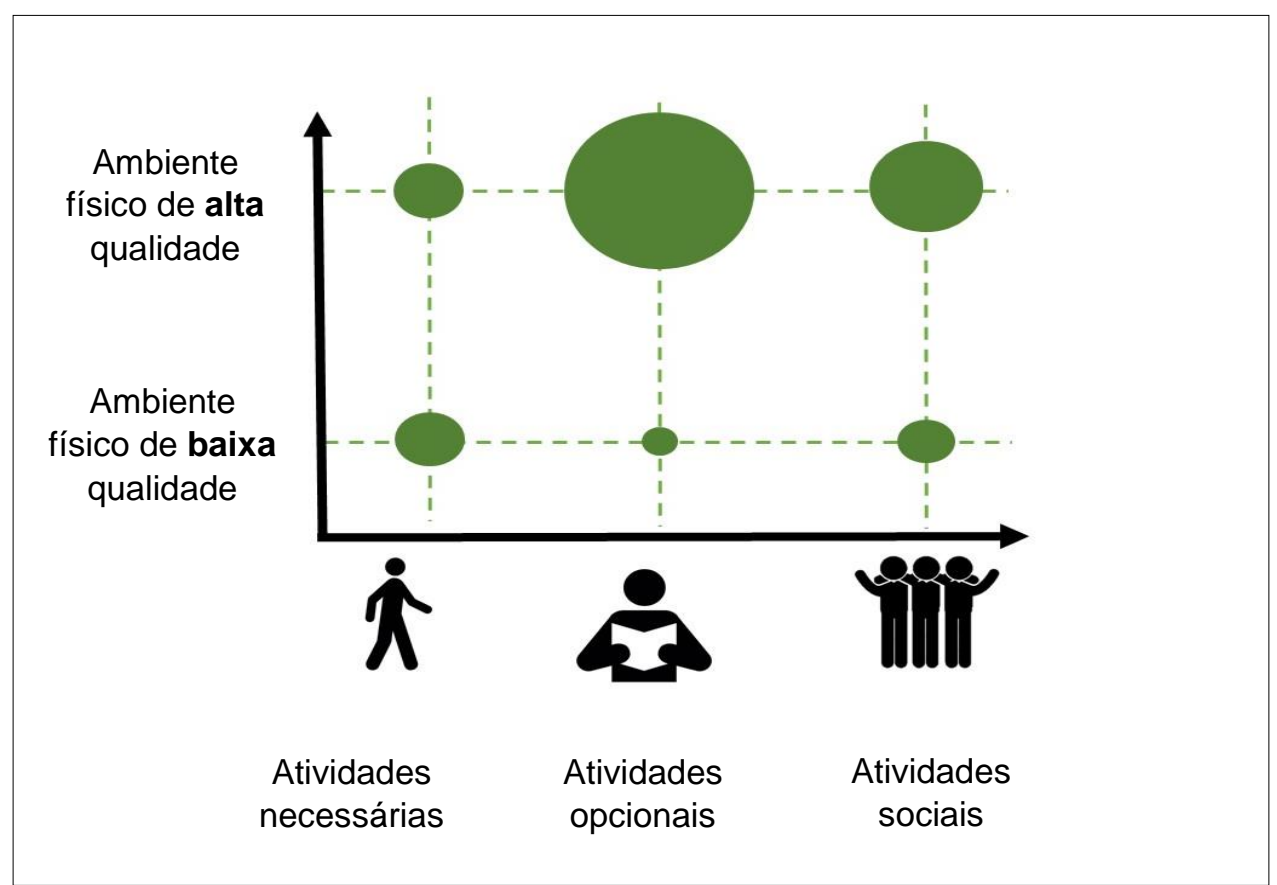

Figura 2: Representação gráfica da relação entre qualidade de ambientes externos e atividades ao ar livre. Fonte: GEHL (2010).

Gehl (2010) analisa a interação intersocial de acordo com a qualidade espacial de cada local, o autor acredita que a vida urbana aumenta em decorrência da qualidade física do ambiente, visto que ambientes de alta qualidade podem elevar a quantidade de atividades opcionais e sociais, dessa forma, espaços de qualidade estimulam a permanência prolongada, trazendo vida para a cidade. Portanto, o espaço público é, segundo Speck (2012) o principal elemento de interação social e da participação do pedestre na vida da cidade, uma vez que o cidadão a pé é o protagonista da reativação, requalificação, animação e integração de áreas urbanas.

Para Gehl (2010), a escala humana é o ponto inicial para melhores condições de vida na cidade, entretanto, atingir este objetivo exige uma drástica mudança no pensamento humano, que muitas vezes está programado para seguir o hábito diário: utilizar os veículos como meio de transporte. 


\subsection{Espaços Urbanos}

\subsubsection{As funções da Rua}

Tendo em vista que urbanismo racionalista teve a proposta baseada na segregação dos espaços de moradia, trabalho, circulação e diversão (MAGNANI, 2003) a rua foi vista por este movimento como um ambiente de desordem e mistura de diferentes tribos, dessa forma, o líder do modernismo, Le Corbusier, afirmou que as ruas poderiam ser riscadas do mapa, visto que não atendiam aos padrões estabelecidos na Carta de Atenas (1933), o arquiteto declarou: "Precisamos matar a rua!" (CORBUSIER, 1989).

Em contrapartida aos conceitos de Le Corbusier, Magnani (2003) aborda a importância da rua sob um olhar antropológico. Para o autor, a rua não exerce somente a função de via, vai muito além, uma vez que a rua resgata a diversidade humana em um local que possibilita o encontro de pessoas conhecidas e desconhecias em um espaço público regido por normas.

Cabe pontuar, que o significado de rua é tema de várias discussões, sendo abordado em vários livros clássicos da literatura brasileira, como no fragmento do livro A Alma Encantadora das Ruas de João do Rio (1908) em que o escritor mostra que a rua vai além das definições modernas, pois para o olhar antropológico, a rua oferece não só o espaço destinado ao fluxo, ela vira local de festas, trajeto em dia de procissão, local de protesto, local de trabalho e de encontro (MAGNANI, 2003).

"Os dicionários só são considerados fontes fáceis de completo saber pelos que nunca os folhearam. Abri o primeiro, abri o segundo, abri dez, vinte enciclopédias, manuseei in-folios especiais de curiosidade. A rua era para eles apenas um alinhado de fachadas por onde se anda nas povoações.

Ora, a rua é mais do que isso, a rua é um fator da vida das cidades, a rua tem alma! " (JOÃO DO RIO, 1908, pg. 26).

O encontro de pessoas nas ruas, nos bairros, forma o que Magnani (2003) denomina de "pedaço". Para ser classificado "do pedaço", precisa-se, primeiramente, existir um território demarcado, um espaço físico que determine os locais de encontro, como o telefone público, a padaria ou um bar, pois esses espaços determinam a fronteira entre: fora de casa "fora do pedaço" e as áreas de encontro "no pedaço". 
Contudo, para o autor, não basta apenas existir um espaço físico em comum, para alguém ser classificado "do pedaço" deve existir uma rede de relações que o façam fazer parte de uma comunidade, desde vínculos familiares, vizinhança, amizade, relações desportivas até a participação em atividades comunitárias.

\subsubsection{UNIVER(CIDADE)}

Uma universidade assemelha-se à uma pequena cidade, pois na instituição também ocorrem encontros de pessoas com ideias e pensamentos diferentes, mas que são unidos por um espaço físico, cursos e disciplinas em comum, e que desenvolvem laços de amizade e relações sociais. Dessa forma, analogicamente, pode-se considerar que dentro de uma universidade existem os próprios "pedaços" citados por Magnani (2003).

Apesar de ser um ambiente fechado e exclusivo (no caso das instituições privadas), o espaço físico da universidade em questão, o Centro Universitário de Brasília (UniCEUB) se assemelha ao projeto urbano da cidade em que está inserido, pois divide-se em blocos, que atendem uma gama específica de cursos, fazendo com que os estudantes e funcionários fiquem reclusos, majoritariamente, em seus respectivos blocos.

Os blocos podem ser associados aos bairros de uma cidade, pois são nestes espaços que se criam pequenos "pedaços". Dentro das universidades, os estudantes, principalmente, começam a se sentir parte daquele grupo devido a características espaciais em comum, como a sala de aula, o curso, a lanchonete que frequenta ou a biblioteca. Além disso, há o fator social, que, intensificado pela característica física, proporciona a criação de laços entre as pessoas e as inserem dentro desta comunidade, do grupo e, finalmente, do "pedaço", dessa forma, essa inserção ocorre devido as relações de amizade, de profissionalismo, de estudo, dentre outros.

E como a cidade, toda universidade possui suas "ruas", que são espaços que, inicialmente, podem ser vistos apenas como local de fluxo, mas que eventualmente exercem funções de atividades escolares, feiras de empreendedorismo, palco de apresentações e até áreas de discussões e debates, ou seja, da mesma forma que ocorre nas cidades, as "ruas" das universidades são responsáveis pela vivacidade e pelos principais meios de encontro.

Os espaços abertos são tão importantes para uma universidade, da mesma forma que as ruas são para as cidades, por isso, o campus deve ser planejado e pensado para as pessoas que ali frequentam (Jacobs, 1961), o que se pode fazer uma analogia com os espaços urbanos públicos, que passam a maior parte do dia e necessitam realizar seus deslocamentos, suas atividades físicas, de lazer e de estudos. Dessa forma, as ruas, os bairros e os centros da 
universidade devem estar em completa harmonia, voltadas para as pessoas, para que haja vida e qualidade no espaço.

No entanto, são poucas as universidades que possuem estes espaços adequados, em alguns casos, estas áreas existem, mas são mal utilizadas e não trazem conforto nem utilidade para os frequentadores e geralmente, são problemas semelhantes aos que ocorrem nos espaços urbanos públicos. Portanto, para compreender melhor o que se passa na escala macro (de uma cidade), deve-se analisar também a escala micro (no caso, a universidade).

Compreendendo a fundo os problemas que ocorrem dentro da universidade, as soluções podem ser postas em prática e, em caso de sucesso, pode-se pensar em uma solução semelhante para a cidade, assim, a universidade pode ser 0 primeiro experimento para se estudar a possibilidade da melhoria dos espaços públicos urbanos da cidade.

\section{Metodologia}

\subsection{Pesquisa quali-quanti}

Os métodos de pesquisa foram definidos como quali-quanti, visam os resultados qualitativos e quantitativos, respectivamente. Os dois critérios são complementares e podem ser aprofundados de modo a obter uma compreensão e explicação mais ampla acerca do tema. É um tipo de pesquisa qualitativa e/ou quantitativa, entendido como uma categoria de investigação que tem como objeto o estudo de uma unidade de forma aprofundada, podendo tratar-se de um sujeito, de um grupo de pessoas, de uma comunidade etc. (PRODANOV, 2013).

A pesquisa qualitativa está relacionada a compreensão e interpretação de determinados comportamentos de um grupo específico, ou seja, não tem o intuito de obter resultados numéricos, mas de apresentar relatórios detalhados, destacando frases dos participantes, trechos e opiniões sobre o assunto. A investigação foi baseada em estudos bibliográficos sobre os temas abordados, como a qualidade dos espaços de convivência, o impacto dos veículos na universidade, a má utilização de áreas destinadas à estacionamentos e sobre a interatividade das pessoas com o lugar que frequentam, no caso, o UniCEUB.

\subsection{Grupo Focal}

Com o objetivo de coletar dados qualitativos, foi utilizado a proposta de Grupo Focal, tal método é descrito por Marková (2003) como sendo uma técnica considerada uma comunicação socialmente situada onde os participantes negociam significados, criam novas significações e produzem, tanto diversidade e divergência de opiniões, quanto consenso. 
Neste contexto, o grupo é formado de quatro a doze participantes que exploram determinado tema proposto pelo pesquisador, a fim de construir um dado dialogado de forma coletiva (MARKOVÁ 2003). O procedimento baseiase na escolha de pessoas de diferentes perfis, que não possuam vínculo, para que não haja influência nos dados e retratem a realidade individual tema questionado. Os entrevistados são informados sobre os objetivos da pesquisa e sobre o sigilo do Grupo Focal, dessa forma, os nomes do indivíduo devem ser alterados e não identificados durante a análise. Além disso, os participantes são esclarecidos sobre a possibilidade de recusar participar da pesquisa, sendo solicitado o consentimento de todos para a gravação do grupo, com o intuito de auxiliar o pesquisador a analisar, posteriormente, as respostas dadas.

O Grupo Focal traz vantagem de ser um método que possui baixo custo e traz resultados rápidos para a pesquisa, além disso, o formato flexível permite que o moderador explore perguntas não previstas durante o procedimento, e ainda, influenciado pelo o ambiente relaxado, as opiniões falsas ou extremadas são minimizadas, proporcionando o equilíbrio e a fidedignidade dos dados.

Os entrevistados são dispostos em uma roda (Figura 3) para que possam identificar todos participantes, além disso há a presença de um mediador, cuja a função é fazer as perguntas e encaminhar o debate para que não ocorram desentendimentos ou a fuga do tema. Ao lado do mediador, é necessário a presença de um auxiliar que irá complementar e anotar as informações captadas durante o diálogo, como reações ou detalhes que ficaram nas entrelinhas. No centro do círculo é colocado um gravador para que o áudio fique em bom tom e possa ser utilizado posteriormente para melhor avaliação.

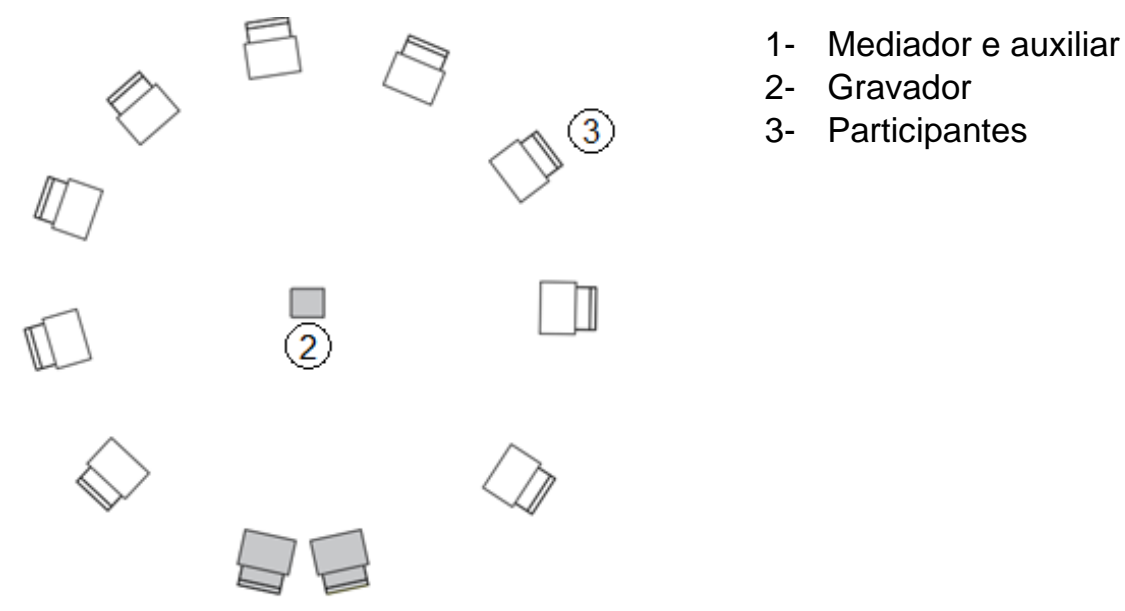

(1)

Figura 3: Modelo de um grupo focal.

Fonte: Arquivo pessoal.

\subsection{Nuvem de palavras}


A partir da transcrição dos áudios gravados em ambos grupos focais, um estudo de contagem de palavras foi realizado, a fim de gerar um gráfico digital, ou nuvem de palavras (Figuras 7.1 e 7.2), que expõe o grau de frequência dos termos citados em um texto, destacando as mais mencionadas, com o objetivo de comparar os pontos mais relevantes nos diferentes grupos.

\subsection{Contagem de pessoas por meio de fotos}

A contagem de pessoas, por meio de fotos, foi uma técnica utilizada para calcular uma estimativa do número de questionários a ser aplicado em cada área. Para fazer o registro fotográfico mais real possível, foi escolhido uma semana sem feriados e em uma quinta-feira, no dia 27/04/2017, a contagem ocorreu durante o intervalo da manhã, entre as 9h20mim e 9h40mim, visto que é o horário de maior concentração de pessoas nas áreas abertas.

\subsection{Aplicação de questionário}

As perguntas dos questionários foram elaboradas com base nas análises realizadas nos dois grupos focais a fim de obter uma comprovação ou uma negação acerca do tema estudado. Para isso, foi aplicado uma amostra de 300 questionários, representando $6 \%$ de erro amostral e $94 \%$ de confiança do número de frequentadores do UniCEUB.

\section{Análise dos resultados}

\subsection{Grupos Focais}

\subsubsection{Grupo Focal 1}

Para melhor compreensão dos resultados obtidos no Grupo Focal 1, o texto foi dividido em 3 etapas: Rotina e Alimentação, Interação e Descanso, uma vez que estes temas foram os mais relevantes durante a análise.

\section{Rotina e Alimentação}

O primeiro Grupo Focal foi realizado com funcionários da instituição de perfis variados, todos atuavam em diferentes blocos (Figura 4) e assumiam diversas funções, dentre os quais, participaram funcionários de limpeza, manutenção, estagiários e atendentes. Para manter o sigilo dos nomes cada um foi atribuído o nome de um deus da mitologia grega.

As perguntas iniciais foram sobre a rotina e o tempo que costumavam passar na universidade, alguns funcionários afirmaram que consideram o UniCEUB a sua casa, pois além da jornada diária, permanecem na instituição para estudar em horários distintos ao período de trabalho. No geral, a maioria costuma 
passar o dia ou muitas horas dentro da universidade e demonstraram que isso é uma realidade comum entre os trabalhadores, tal como define Hera:

"A gente mora no CEUB, só vamos em casa dar um cheiro no filho, falar com o velho e no outro dia já estamos aqui".

Devido a longa jornada de trabalho, os funcionários reclamam da falta de refeitórios, afirmando que a demanda é grande e que os espaços não foram projetados para a quantidade de pessoas que trabalham, atualmente, na universidade. Destacam também que existem poucos assentos e que precisam comer rapidamente para que os outros colegas possam revezar os lugares. Os funcionários falaram da existência de um refeitório subterrâneo no bloco 2 (Figura 4) e apesar de ser apontado como um dos maiores da universidade, relatam a superlotação em horários de almoço. Apolo confirma que alguns estudantes descem para almoçar no refeitório de funcionários, fazendo com que o espaço se torne ainda mais cheio. Poseidon mudou seu local de refeição e passou a almoçar no Píer (Figura 4), mesmo não sendo o lugar mais agradável, ele afirma que por enquanto está sendo sua melhor opção, pois:

"O fluxo de funcionários que vai almoçar no bloco 12 é muito grande. Você nem sentou e já tem que levantar, por que tem gente esperando para comer sentado".

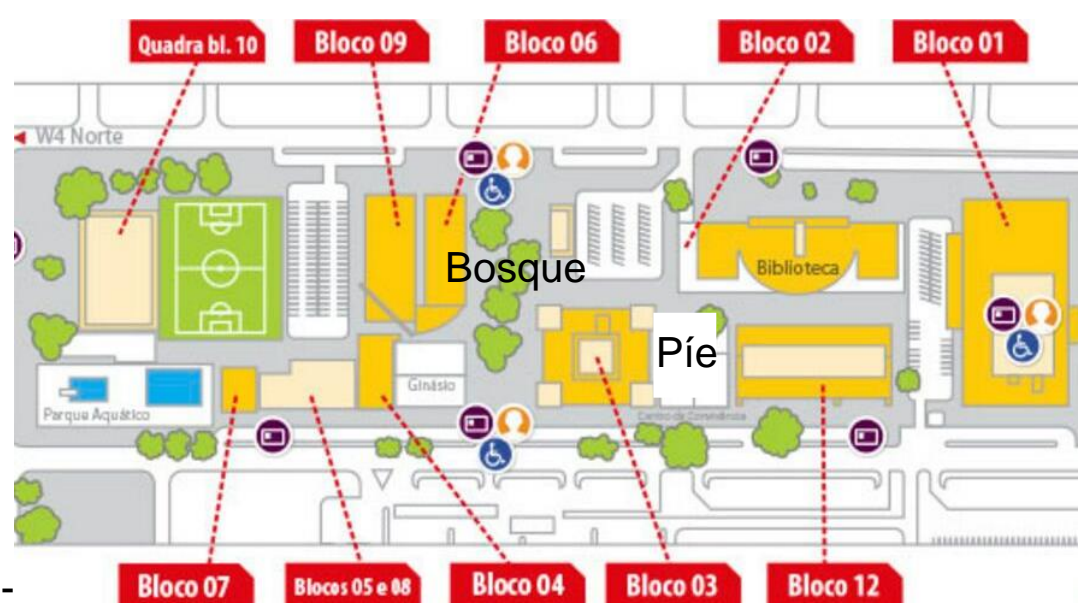

Figura 4: Mapa do UniCEUB, numeração dos blocos.

A opção de almoçar no Píer foi a menos favorável para os participantes, pois a maioria prefere comer em lugares fechados e discretos para evitar muita exposição, no caso de Ártemis, estagiária do CEUB, almoçar no Píer seria uma opção, porém a participante explicou que normalmente opta por restaurantes fora da instituição, porque apesar de ter o vale alimentação, nenhuma das lanchonetes o aceita para almoço, somente para lanches, forçando-a a sair da universidade para fazer a refeição ou a levar a comida de casa. 
De acordo com Hefesto, o bloco 5 possui uma pequena copa que dependendo do horário fica cheia e faz com que as pessoas fiquem do lado de fora por acharem muito abafado e fechado, ele gostaria que tivesse um lugar mais adequado, pois muitas vezes ele almoça no corredor, tornando a atividade desagradável. Ele afirma: "Não é legal almoçar em um local que as pessoas estão entrando e estudando”.

\section{Interação}

Ao serem questionados sobre os espaços que utilizam para conversar e interagir com amigos a resposta é unânime, os funcionários relatam que a convivência e as relações sociais são restritas aos blocos em que trabalham ou estudam, e dificilmente conhecem pessoas de outros blocos. Posseidon e Ártemis confessam que seus contatos são apenas no bloco onde realizam suas atividades, esta última afirma que não tem muita interação devido à enorme área que a instituição ocupa e por ela ser dividida em blocos, e completa que só chegou a ver as reformas realizadas no bloco 1 (Figura 4) devido a uma atividade necessária que exigiu sua participação. Posseidon explicou sua interação do seguinte modo:

"Geralmente a gente interage no bloco onde trabalha. Ali é onde você conhece os funcionários, os professores e interage com eles, até com os alunos. Eu trabalho no 6 e no 9 então só tenho contato próximo com as pessoas desses blocos. Interação geral é complicado...".

Eis um ponto que faz analogia à obra de Magnani (2003), pois a delimitação física faz com que o funcionário ou estudante fique vinculado ao bloco de forma simbólica, tornando-o parte de um todo, podendo classificar os usuários em "pertencentes" a determinado bloco e, quando o contrário, como "fora do bloco" ou, como o autor aborda, "fora do pedaço". A categoria pedaço é formada por dois elementos básicos: um de ordem espacial, físico, sob o qual se estende uma determinada rede de relações, no caso, os blocos. No entanto, não basta passar pelo bloco ou mesmo frequentá-lo para "ser do pedaço", é preciso estar situado numa peculiar rede de relações que combina laços (MAGNANI, 2003), como os tipos cursos ou a função que exerce no trabalho.

O termo na realidade designa aquele espaço intermediário entre o privado (os blocos) e o público, onde se desenvolve uma sociabilidade básica, mais ampla que a fundada nos laços familiares, porém, mais densa, significativa e estável que as relações 
formais individualizadas impostas pela sociedade. (MAGNANI, 1998, p.116).

Apesar de todos concordarem que a interação é restrita aos blocos, Hefesto e Hades acreditam que seus cargos possibilitam maior interação com as pessoas, uma vez que trabalham na secretaria e portaria, porém, apesar de terem maior interação que os demais funcionários, ela só acontece devido as atividades necessárias (GEHL, 2010) referentes ao contato mais direto com o público. As trocas sociais são feitas devido ao cargo que eles possuem, não são atividades sociais, nem opcionais, fazendo com que o homem confunda as barreiras entre lazer e trabalho e aceite-as como interação, neste contexto Hades comenta:

"A gente tem contato com o pessoal técnico de outros setores, eles sempre estão lá. $A$ gente conversa sobre o necessário, mas apenas profissionalmente. ".

\section{Descanso}

Em unanimidade, os funcionários sentem falta de locais adequados para 0 descanso no horário do almoço, eles permanecem em seus setores, lugares fechados e afirmam que não existem espaços de qualidade para estes momentos. Quando questionados sobre a possibilidade de descansar em áreas abertas, como o "Bosque", a expressão geral é de medo, seguido por momentos de silêncio e poucas respostas. A inquietação sobre o motivo dessa restrição logo veio à tona; a maioria tem vergonha, medo que o emprego seja prejudicado por descansarem publicamente e que recebam punições, um dos participantes afirma já ter ouvido a seguinte frase de seu chefe: "Soldado que está no quartel é porque quer serviço".

Além do medo de descansar, a maioria do grupo afirma já ter trabalhado durante o intervalo várias vezes, sendo uma das razões para muitos almoçarem fora da instituição ou em blocos onde não são conhecidos, pois assim tiram o foco de si para não terem serviço durante o horário de almoço com, normalmente, duração de 1 hora. Porém, por mais que a mudança de blocos seja uma opção, Posseidon afirma que mesmo estando em outro lugar, já foi interrompido de seu almoço para realizar algum serviço. Ártemis compartilha de situações semelhantes, por isso ela procura ficar escondida, mas confessa que sempre entram professores e a chamam para algum serviço. Ela lamenta também evitar ficar em áreas abertas, pois só pelo fato de fato de estar uniformizada, alguns a acionam com dúvida e ela acaba fazendo o atendimento, trabalhando fora do seu horário. Estes problemas foram comuns a todos os participantes, e Hera dá o seu depoimento: 
"Quantas vezes no meu horário de almoço eu recebo a chamada "Sala tal aconteceu tal coisa", eu vou por respeito aos professores e pela instituição, pelo trabalho. Eu vou, e ainda vou sorrindo."

O medo e a vergonha são motivos para alguns funcionários procurarem lugares isolados ou até saírem da universidade no horário do almoço, exemplo do caso de Ares, sendo funcionário e estudante, geralmente ele passa o dia no UniCEUB e quando pode, vai para a casa de colegas que moram próximos para tentar descansar. Ele expõe:

"Tem dia que eu não vou embora e para descansar é uma dificuldade. Como eu moro longe, às vezes tento ir para a casa do meu amigo, quando não dá a gente tenta segurar por aqui. Só vamos para tirar um cochilo, por que às vezes é o que necessitamos naquele momento, se não a gente perde todo o foco. Muitas vezes eu estou estudando, e às vezes eu cochilo, quando eu vejo, nem lembro o que eu estava estudando mais."

O grupo fez apelo para a implementação de espaços de descansos destinados somente aos funcionários e professores, desejam áreas mistas (abertas e fechadas) para que todos possam sentir-se à vontade. A maioria prefere que os alunos também tenham um espaço como este, porém, a exclusividade seria para que os primeiros não perdessem este espaço e que fosse algo mais restrito.

Além das áreas de descanso, algo salientado foi a criação de um refeitório central, grande e que pudesse atender a todos, fazendo com que os estudantes e funcionários tivessem mais oportunidades de escolha de alimento e de lugares. Juntamente a isso, eles esperam que haja mais conscientização dos alunos e dos demais funcionários para que respeitem os horários de descanso de cada um, visto que é uma necessidade de todos.

A possibilidade de criação de áreas voltadas para os funcionários pode dar uma boa imagem para o UniCEUB e alavancar a vontade de trabalho dos colaboradores, e acredita-se que a iniciativa pode ser implementada e analisada para que outras instituições possam ser inspiradas a fim de aplicarem estas pequenas soluções para melhorar o dia a dia de todos os usuários. Hera afirma isto em um de seus comentários a respeito do olhar generoso da universidade sobre os seus funcionários: 
"A instituição se tornaria um modelo. Iria implantar e daria mais força para as outras instituições acatarem este projeto, seria legal, seria uma forma diferente de pensar nos funcionários."

Ao serem questionados sobre as possíveis áreas para essas implementações, os estacionamentos internos e privativos foram apontados como locais em potencial, que se encaixariam nas descrições dos entrevistados, porém ao perceberem que estas vagas atendem a professores e alguns funcionários a opinião geral é que poderia trazer discussões e problemas, mas acreditam que no final poderia ser uma boa solução e traria mais vivacidade para o campus.

\subsubsection{Grupo Focal 2}

Para melhor compreensão dos resultados obtidos no Grupo Focal 2, o texto foi dividido em 3 etapas: Rotina e Alimentação, Estacionamentos e Pedestres e Ciclistas, uma vez que estes temas foram os mais relevantes durante a análise.

\section{Rotina e Alimentação}

O segundo Grupo Focal foi realizado com estudantes da instituição de perfis variados e de diferentes cursos e blocos (1 ao 12, Figura 4). Participaram alunos de Arquitetura e Urbanismo, Direito, Engenharias e Jornalismo. Para manter o sigilo dos nomes foi atribuído o nome de um deus da mitologia romana para cada participante.

O segundo grupo também teve discussões similares às expostas no primeiro grupo focal. Ao serem questionados sobre o horário que passavam na universidade, a maioria respondeu que é comum ficarem o dia inteiro, pois muitos moram em cidades satélites, induzindo os estudantes a permanecerem o dia no Plano Piloto e retornarem às suas casas apenas à noite, devido as longas distâncias e o trânsito pesado, dessa forma, os alunos realizam várias refeições dentro do UniCEUB ou até mesmo nos restaurantes do entorno.

Como esperado, o segundo grupo também reclamou dos espaços destinados à alimentação dentro da universidade, alegando que além da pouca variedade no "Píer", os preços são altos. Plutão acredita que exista a venda casada entre as lanchonetes, porque, segundo ele, quando um preço aumenta em algum estabelecimento, os outros acompanham. No entanto, Baco descobriu que os donos dos restaurantes e lanchonetes precisam continuar pagando o caro aluguel, mesmo em dias de feriado e durante os períodos de férias, de acordo com o vendedor, se o preço de coisas baratas não for alto, ele não conseguiria pagar o aluguel. 
A incompreensão dos alunos com a existência de salão de beleza e loja de roupas na praça de alimentação faz a maioria se sentir incomodada, pois, para eles, existem outras prioridades a serem supridas. Minerva expôs a opinião sobre o assunto, a aluna acredita que a falta de copas e refeitórios é um problema para pessoas que possuem restrição alimentar, o que dificulta 0 manuseamento de alimentos e compromete a saúde de inúmeras pessoas:

"Quando abriu essa loja de roupa no "Píer" eu fiquei impressionada. Por que o CEUB não utiliza esse espaço para fazer um C.A.? Fazer uma copa com vários micro-ondas e com algumas pias para a gente lavar os alimentos e utilitários?"

Os participantes do segundo grupo focal acreditam que falta integração entre os blocos do UniCEUB (Figura 4) deveria ser resolvido, para eles o lugar mais agradável de se estar é o Bosque, devido a vegetação e o ambiente agradável, e concluem também que seria interessante a criação de mais áreas verdes dentro da universidade para estimular a permanência dos estudantes por mais tempo, além de se tornar um lugar agradável que possa gerar espaços de qualidade para descanso e estudo. A aluna Vênus explica:

"Eu estudei em uma Universidade fora e eu via muito o uso da grama, melhorava muito a qualidade de vida de qualquer pessoa. A gente tem um trauma de passar o dia aqui no CEUB porque é muito desconfortável, mas lá todo mundo ia para lá mesmo no dia que não tinha aula, mesmo quando não tinha nada para fazer. Todo mundo levava sua toalhinha e sentava na grama, fazia piquenique. Aqui não, não vejo nem a possibilidade. "

\section{Estacionamentos}

Existem vários estacionamentos externos ao UniCEUB (Figura 5), os $\mathrm{A}$, B e C que são utilizados majoritariamente pelos estudantes da universidade, uma vez que professores e alguns funcionários possuem acesso ao estacionamento privativo do campus (1, 2 e 3 ). A Figura 5 mostra a desproporcionalidade entre as áreas construídas e as destinadas aos veículos, sendo notório que a segunda é superior à primeira, e este fator desencadeia uma série de prejuízos à instituição. 


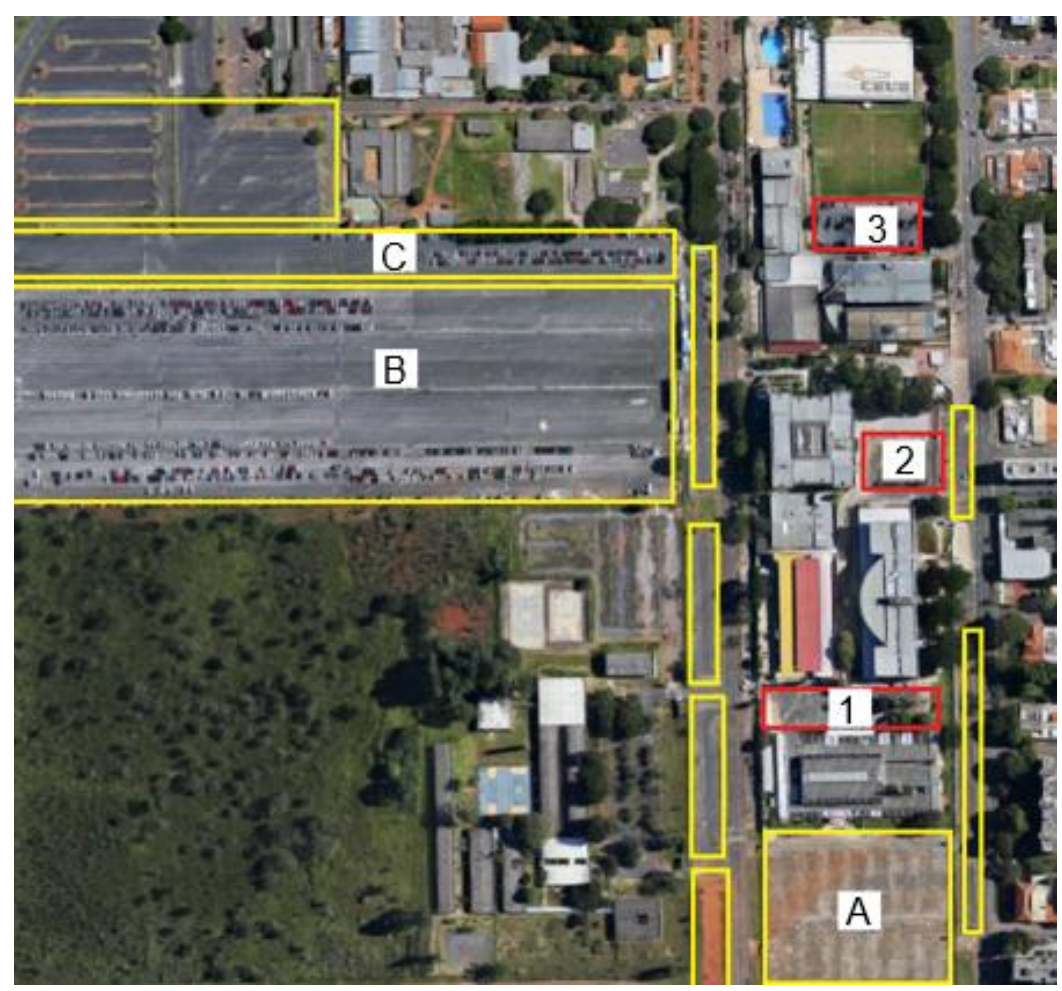

Figura 5: Mapeamento dos estacionamentos ao redor e dentro do UniCEUB.

Vale ressaltar que o estacionamento A consta com aproximadamente 500 vagas e custa $R \$ 3,00$, sendo destinado somente aos frequentadores da universidade. Já os estacionamentos $\mathrm{B}$ e $\mathrm{C}$, embora próximos, apresentam distinções: o B é o maior, com capacidade para 2.000 carros, é gratuito aos estudantes da universidade, e gerido pela empresa Auto Park. O C possui 560 vagas e é aberto ao público, não tendo vigilância.

Conhecido como "infinito", a grande distância do estacionamento B até os prédios da universidade inibe diversas pessoas de deixarem o carro ali, fazendo com que muitos estudantes estacionem em vagas irregulares ou até mesmo, em vagas improvisadas. Segundo os participantes do segundo grupo focal, essas soluções acontecem também por que, segundo eles, estas áreas ( $B$ e C) são as mais perigosas para se estacionar, uma vez que carece de iluminação, segurança e monitoramento. A segurança foi o fator do grupo mais criticado pelos participantes no quesito segurança, pois todos afirmaram sentir medo ao deixar os veículos nas áreas de $\mathrm{B}$ e $\mathrm{C}$, principalmente nos horários noturnos. A situação tornou-se mais preocupante quando Vênus confirmou que o estacionamento C foi apelidado de "estuprinho", devido a casos de assédio, assaltos e roubos que aconteceram no local.

Após relatarem os problemas existentes, os participantes apontaram possíveis soluções para melhorar os estacionamentos B e C, como a instalação de uma melhor iluminação, incentivo de inserir monitoramento e a criação de passarelas cobertas para evitar desconfortos em dias chuvosos ou muito quentes. Marte acredita que essas pequenas medidas não apresentam alto investimento e podem auxiliar muitos estudantes a evitarem futuros problemas, além de proporcionar mais conforto e segurança para os usuários. 
Por outro lado, as opiniões sobre os estacionamentos internos (1, 2 e 3) são diferentes dos externos, pois devido estarem dentro da universidade, possuem boa iluminação e segurança, no entanto são privativos de professores e de alguns funcionários da instituição, o que causa certo incômodo nos estudantes. No geral, os alunos afirmam a existência um estacionamento subterrâneo para os professores e que não há necessidade de disponibilizar tantas vagas para eles. Cabe apontar que os estacionamentos são considerados áreas mortas, uma vez que é destinado apenas para abrigar os veículos, quando não exercem essa função, não possuem utilidade.

Marte declarou que os estacionamentos internos (1, 2 e 3) estão localizados estrategicamente e que são áreas em potencial para serem transformadas em lugares mais agradáveis para todos no UniCEUB, ao afirmar:

"O estacionamento em frente ao bloco 2 (estacionamento 2), por exemplo, acaba sendo desnecessário, já que existe o subsolo e toda aquela área poderia ser arborizada para aumentar a área do "Bosque", porque não cabe todo mundo, essa é que é a verdade. Num dia ensolarado, as pessoas que saem por último acabam "sobrando", porque lá já está cheio."

Cabe destacar que os alunos lamentam a falta de áreas destinadas para descanso e convívio dentro da universidade, para Febo, o UniCEUB é visto apenas como um local para realizar atividades necessárias (GEHL, 2010), pois ao final do horário de aula a maioria dos estudantes partem para outros lugares, diferentemente do exemplo das universidades no exterior citado pela aluna Vênus. No entanto, todos concordaram que há a possibilidade de tornar a instituição um lugar mais confortável com pequenas intervenções, pois afirmam também que gostariam de passar mais tempo, caso esses espaços existissem.

\section{Pedestres e ciclistas}

Segundo os participantes, existem muitos estudantes e professores que moram em locais próximos à universidade, Febo, um dos colaboradores do grupo focal, reside em uma quadra próxima, e afirma que ir ao UniCEUB a pé ou de bicicleta tornou-se uma rotina agradável, porém, geralmente sua irmã 0 acompanha, mas ela, por sua vez, prefere utilizar o carro da família, mesmo morando a poucos minutos da instituição. Para ele, a falta de incentivo da utilização de outros meios de transporte é ruim para os estudantes, ele reclama sobre a falta de bicicletários e acredita que a quantidade existente não atende à demanda, além de estarem localizadas em pontos distantes dos blocos e que, por sua vez, não estimulam os moradores próximos a utilizarem esse meio de transporte. 
Segundo os participantes, cabe à universidade criar estratégias para suavizar os problemas gerados pelo transporte motorizado, e a opção sugerida pelos estudantes é a criação de campanhas internas para incentivar a Carona Solidária, que além de diminuir o número de veículos, favoreceria o contato e a amizade entre os estudantes e professores. Além disso, eles indicam a criação de campanhas e o incentivo ao uso de bicicletas e a mobilidade a pé, principalmente para aqueles que moram em regiões próximas, segundo os participantes, essas medidas poderiam tornar o ambiente mais convidativo e menos desgastante.

\subsubsection{Nuvem de palavras}

A nuvem de palavras é um gráfico digital que permite analisar o grau de frequência dos termos mais comentados durante um texto, para isso, os áudios dos grupos focais foram transcritos e todo o texto foi estudado. Os pontos mais relevantes no Grupo focal 1, com os funcionários, gerou uma nuvem que destaca as palavras na Figura 6, confirmando que a maioria dos funcionários sentem falta de espaços, de lugares para descansar. Além disso, as das palavras que mais se destacaram foram "Gente" e "Funcionários", mostrando que um funcionário da instituição, apesar de trabalhar ali, também é gente, e possui os mesmos direitos de qualquer cidadão, como os em destaque na nuvem de palavras (Figura 6).

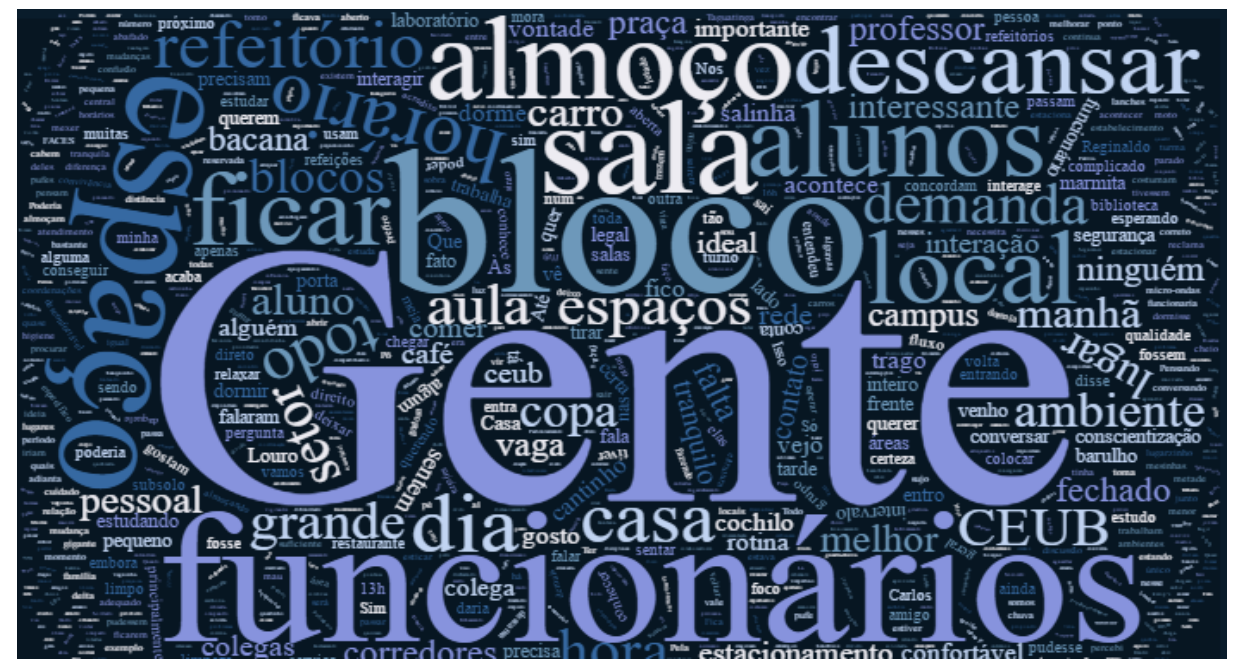

Figura 6: Conjunto de palavras mais citadas no grupo focal 1, com funcionários.

Já no caso do grupo de palavras dos estudantes (Figura 7), percebe-se que algumas são correspondentes às obtidas no estudo do Grupo Focal dos funcionários, e ressaltam que há o desejo de mais espaços de qualidade. 


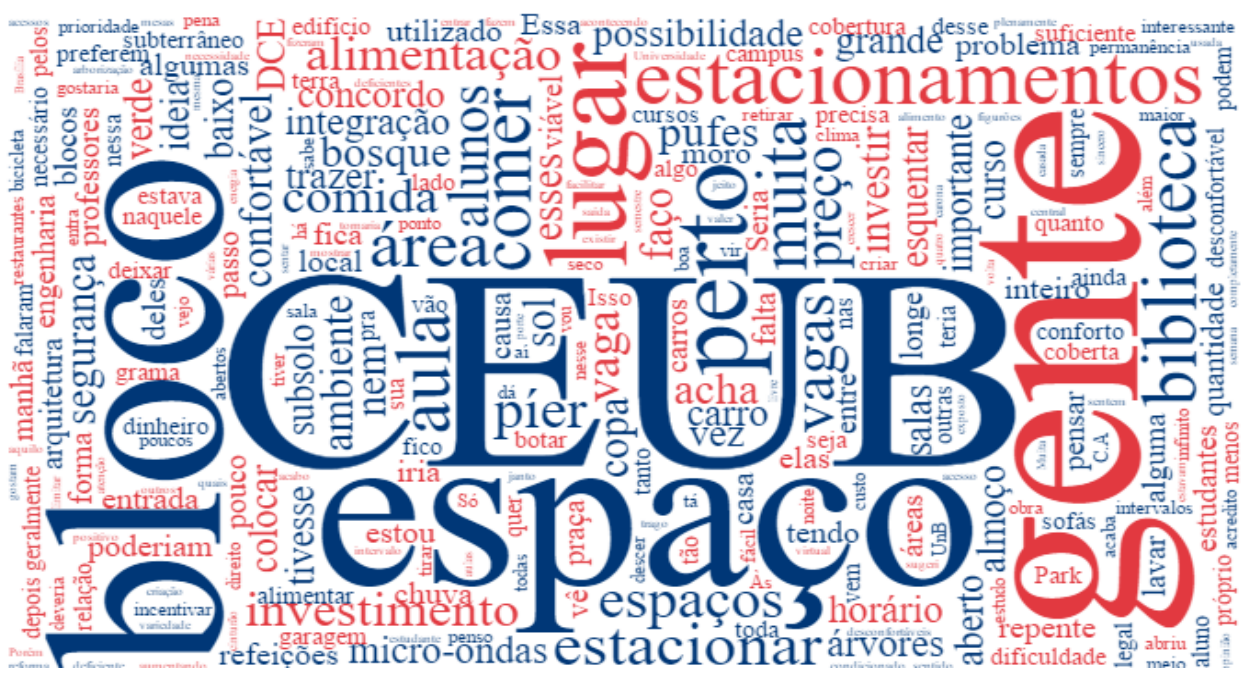

Figura 7: Conjunto de palavras mais citadas no grupo focal 2, com estudantes.

\subsection{Contagem de pessoas por meio de fotos}

Após a realização da etapa qualitativa com os grupos focais, foi necessário dar continuidade à pesquisa, sendo assim, iniciou-se a elaboração dos questionários e, simultaneamente, foi iniciada a pesquisa quantitativa com a contagem de pessoas a fim de definir os locais de aplicação dos questionários dentro da universidade, sendo definido que os questionários só seriam aplicados em áreas abertas da instituição (Figura 8), visto que o tema central da pesquisa é analisar a qualidade dos espaços coletivos.

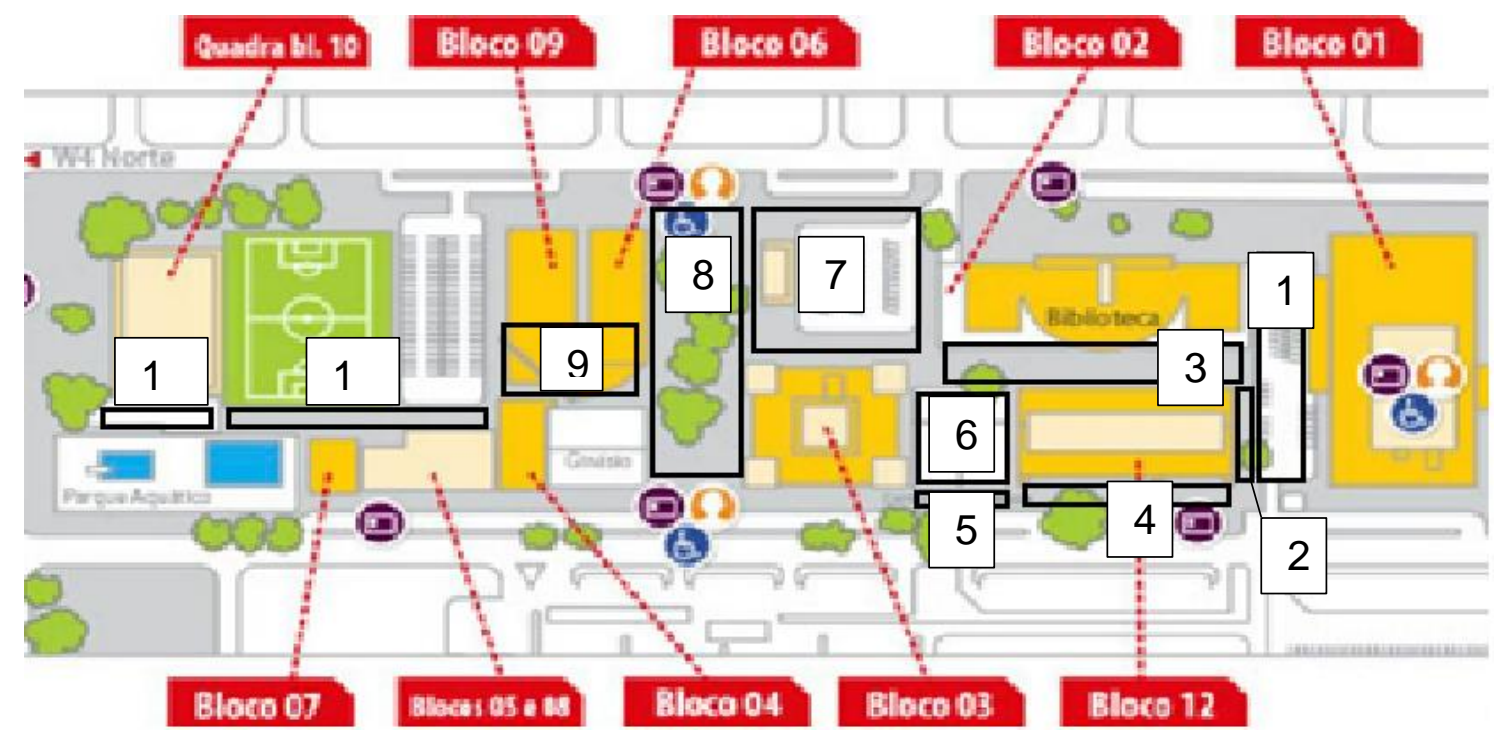

Figura 8: Áreas escolhidas para a contagem de fotos. 
Para compreender a intensidade de fluxo de cada ponto demarcado (Figura 8) foi aplicado um gráfico de intensidade, representado por cinco bolinhas, classificando a intensidade de 1 a 5 , a primeira representando "baixa intensidade de fluxo" e a última "alta intensidade de fluxo", dessa forma, este mecanismo proporciona um melhor entendimento da imagem.

Modelo dos gráficos de intensidade:

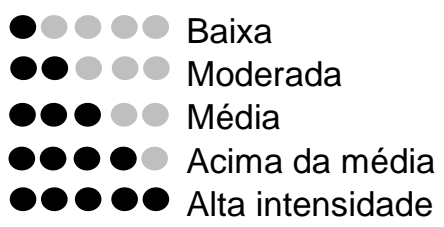

\section{Ponto 1}

O ponto 1 é onde se encontra o estacionamento 1 (Figura 8), esta área conecta todo o UniCEUB com o Bloco 01, onde se situa o setor administrativo e financeiro, além de existir anfiteatro e salas de aula que são importantes para vários cursos. A fraca intensidade do fluxo de pessoas ocorre devido o estacionamento, tornando o local apenas de passagem, portanto, os questionários aplicados nessa área ficaram mais voltados para as lanchonetes que existem no Bloco 01, uma vez que a quantidade de pessoas no estacionamento parecia estar com pressa e, portanto, apenas de passagem (Figura 9).

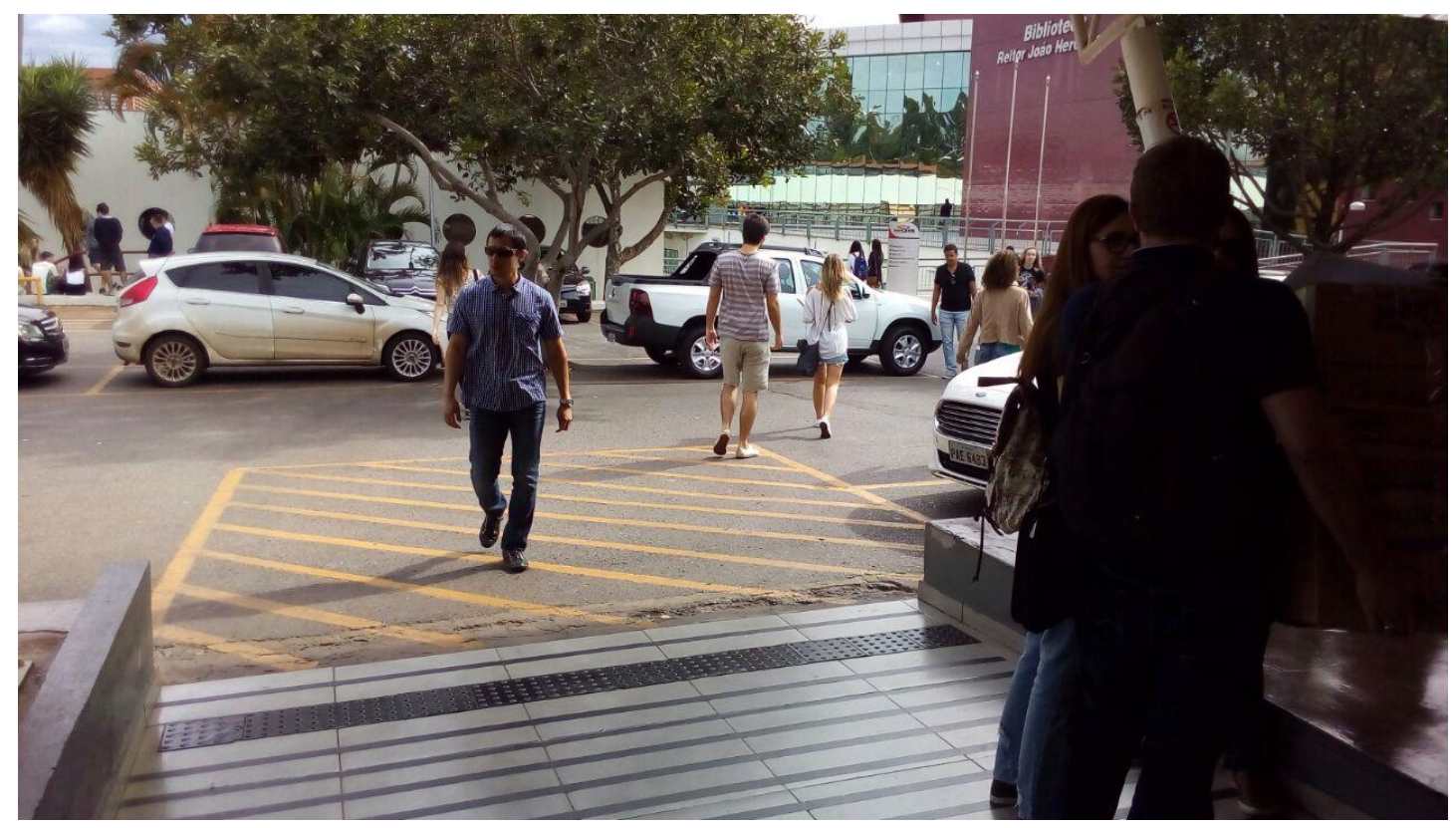

Figura 9: Ponto 1: Intensidade de fluxo:

\section{Ponto 2}


O ponto 2 (Figura 10) é uma área de convivência que acolhe vários estudantes do Bloco 12, majoritariamente, alunos dos cursos de Comunicação. Conhecido como "fumódromo", várias pessoas se reúnem no local, e mesmo não havendo muito espaço, conseguem encontrar um jeito de se acomodarem. Há relatos de que muitos estendem toalhas e cangas nos canteiros de gramas para passarem os intervalos, isso mostra o sentimento de falta de espaço, mesmo quando o local não foi projetado para tal.

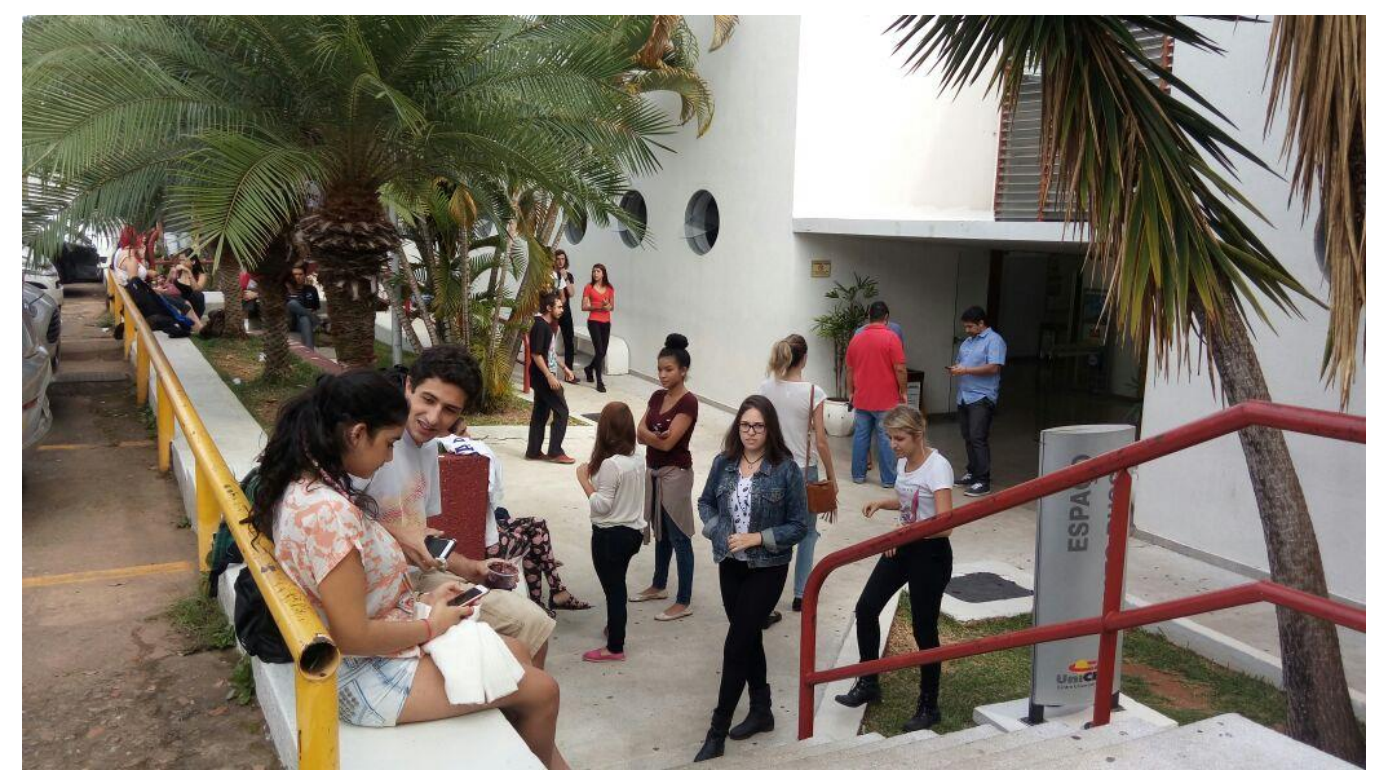

Figura 10: Ponto 2: Intensidade de fluxo:

\section{Ponto 3}

O ponto 3 (Figura 11) assemelha-se ao primeiro, pois é uma área apenas de passagem. Marcada pelo longo paredão sem portas (GEHL, 2010) é uma área desinteressante e sem vida que cumpre sua função exclusiva de conexão entre as áreas. 


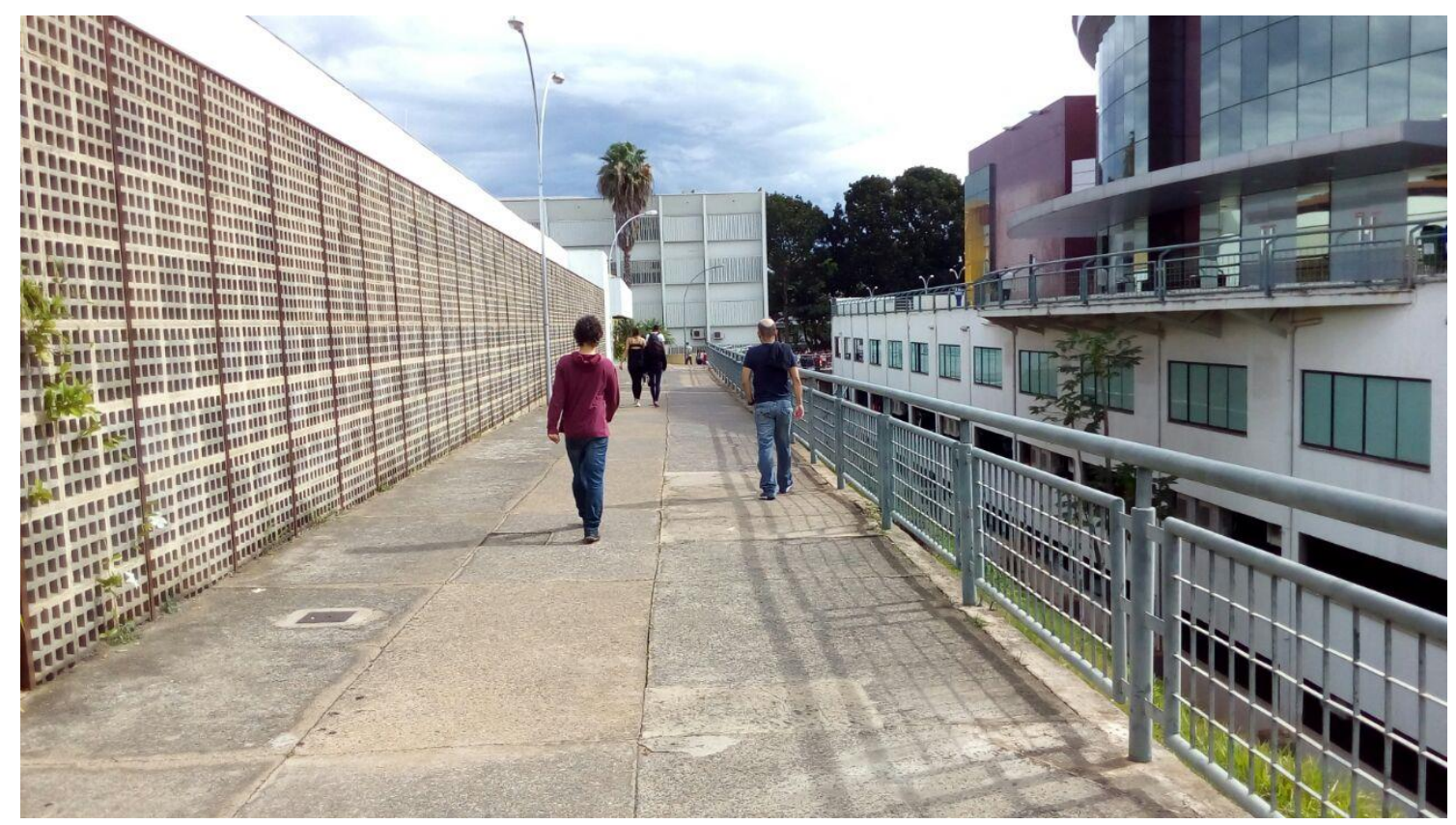

Figura 11: Ponto 3: Intensidade de fluxo:

\section{Ponto 4}

O ponto 4 (Figura 12) também se assemelha ao 1 e ao 3, está localizado atrás do Bloco 12 e exerce função de corredor e de um pequeno estacionamento, é uma área totalmente morta, visto que é um local de serviços e não possui características acolhedoras.

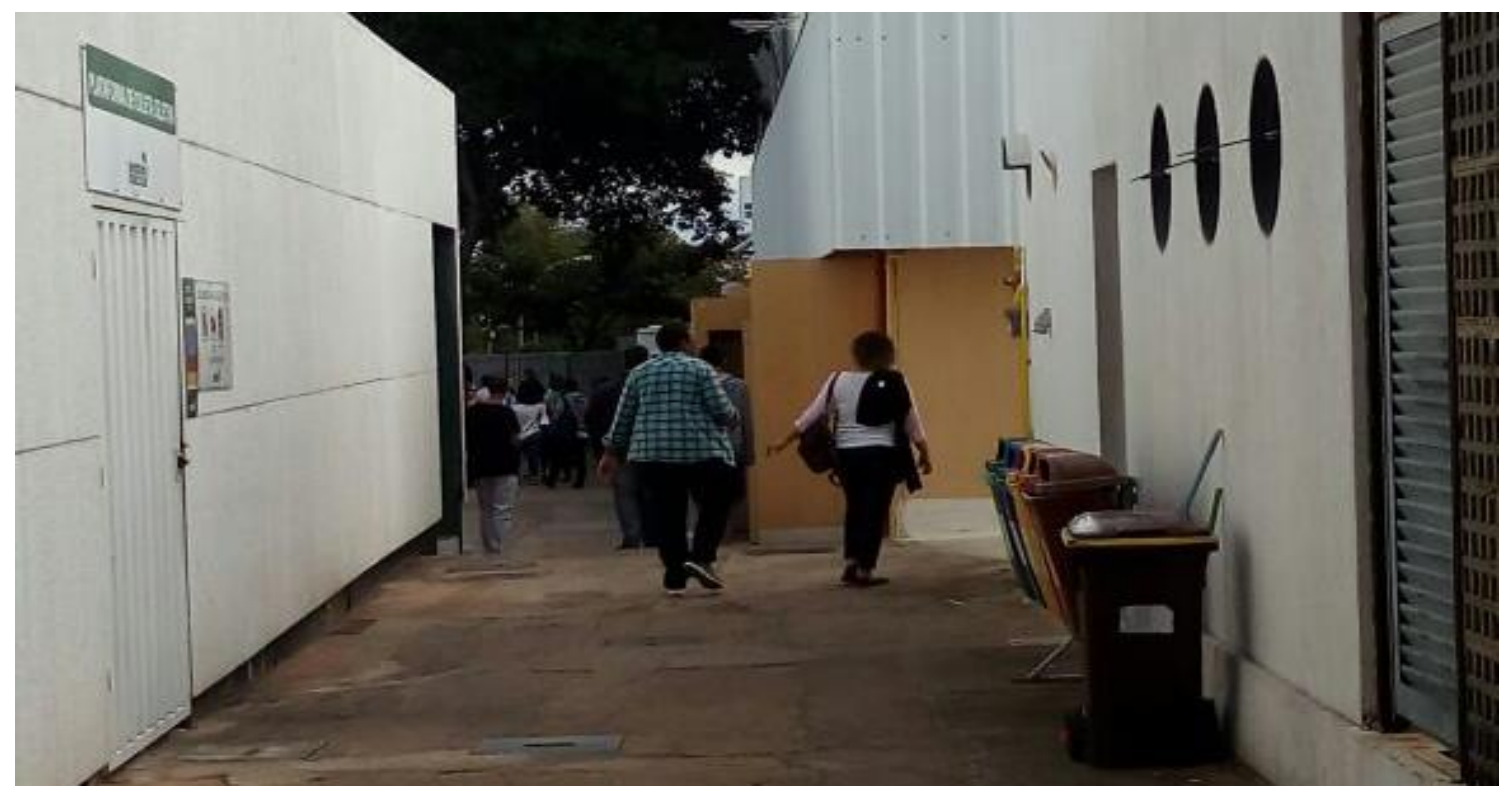

Figura 12: Ponto 4: Intensidade de fluxo:

0000

\section{Ponto 5}

O ponto 5 é uma boa área de convivência próxima ao ponto 4 (Figura 13), nela existem algumas mesas e bastante arborização, onde os estudantes constumam descansar e socializar durante os intervalos, sendo possível sempre encontrar alguém neste local. 




Figura 13: Ponto 5: Intensidade de fluxo:

\section{Ponto 6}

O ponto 6 (Figura 14) é uma das áreas mais cheias de toda a universidade, principalmente nos intervalos das aulas e no horário de almoço, visto que se trata da grande praça de alimentação do campus, conhecida como "Píer", onde abriga restaurantes, lanchonetes, livraria, loja de roupas, papelaria, salão de beleza e banco.

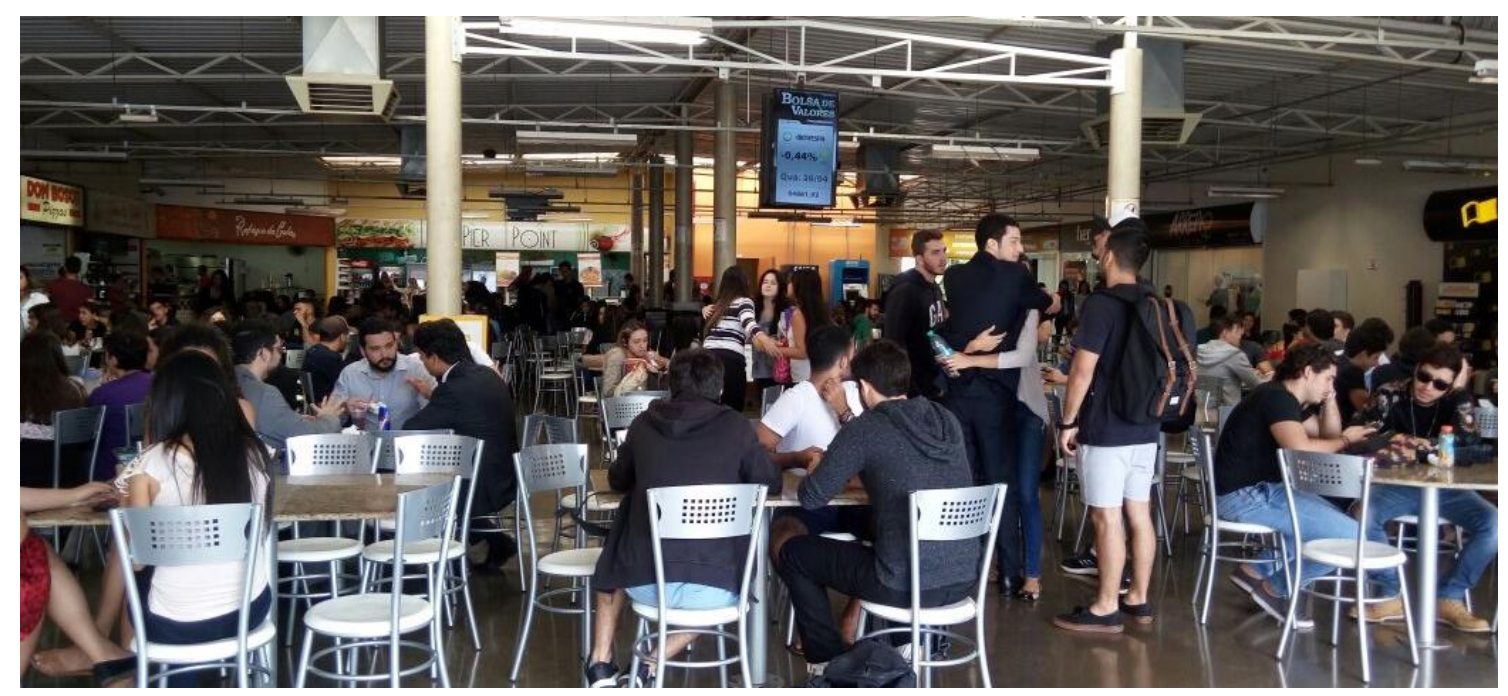

Figura14: Ponto 6: Intensidade de fluxo:

\section{Ponto 7}

O ponto 7 (Figura 15) está localizado no centro geométrico da instituição e é uma área com potencial para possíveis espaços de convivência, porém está sendo utilizada atualmente pelos veículos. O estacionamento, com a utilização da fita, exclui os pedestres e os força andarem à margem dos carros, 
dificultando o acesso ao Bloco 02, que muitas vezes é usado pelos estudantes como rota para chegar ao prédio.

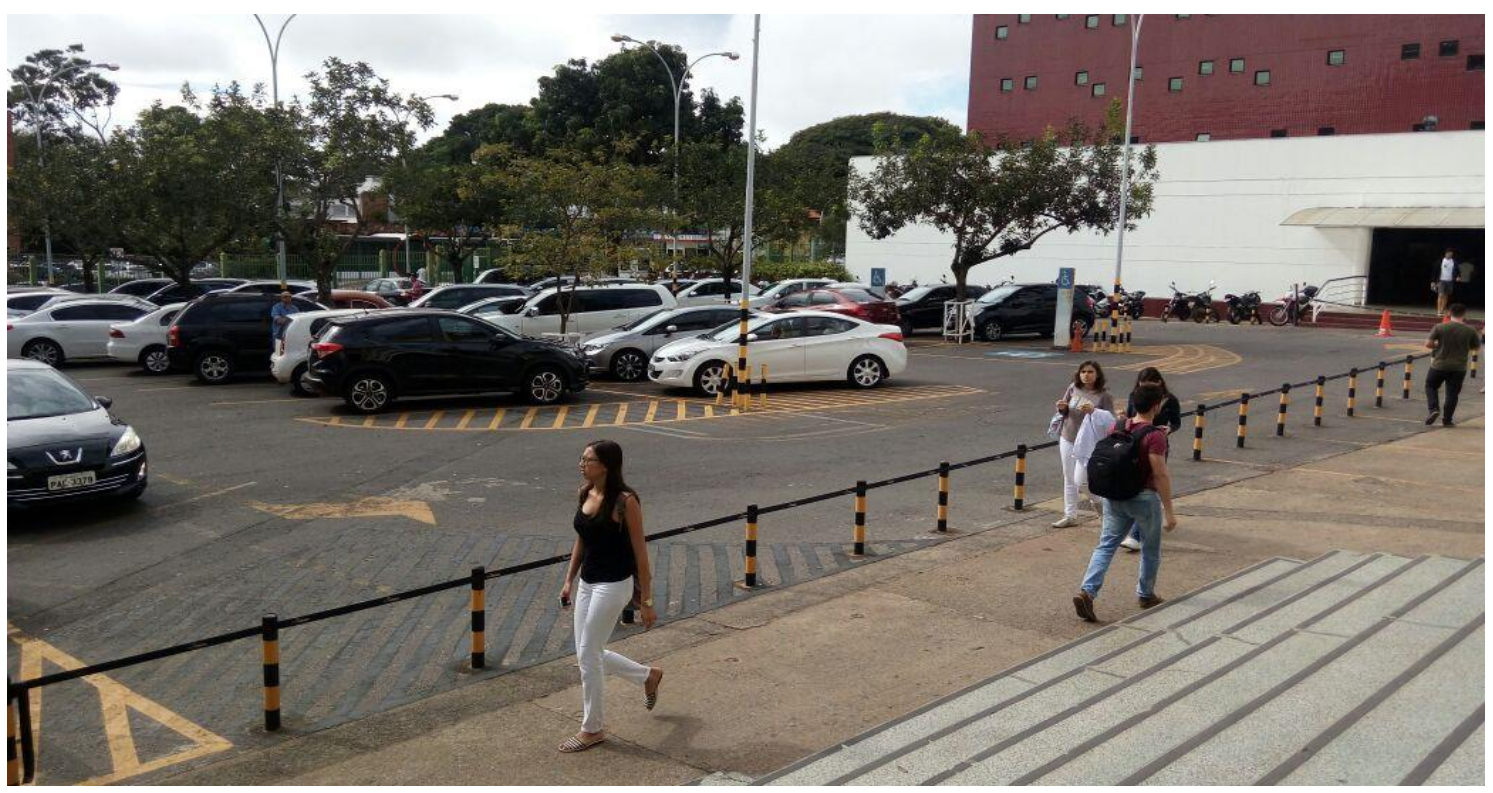

Figura 15: Ponto 4: Intensidade de fluxo:

\section{Ponto 8}

Em contraste com a área morta do estacionamento, o ponto 8 é apelidado de "Bosque" (Figura 16) por ser uma área bastante arborizada e agradável, por causa disso, é o local com maior fluxo de estudantes de todos cursos. O local foi citado por um dos alunos do grupo focal 2 como o mais agradável de toda a universidade, porém, por ser muito cheio, inibe alguns de passarem o tempo livre ali.

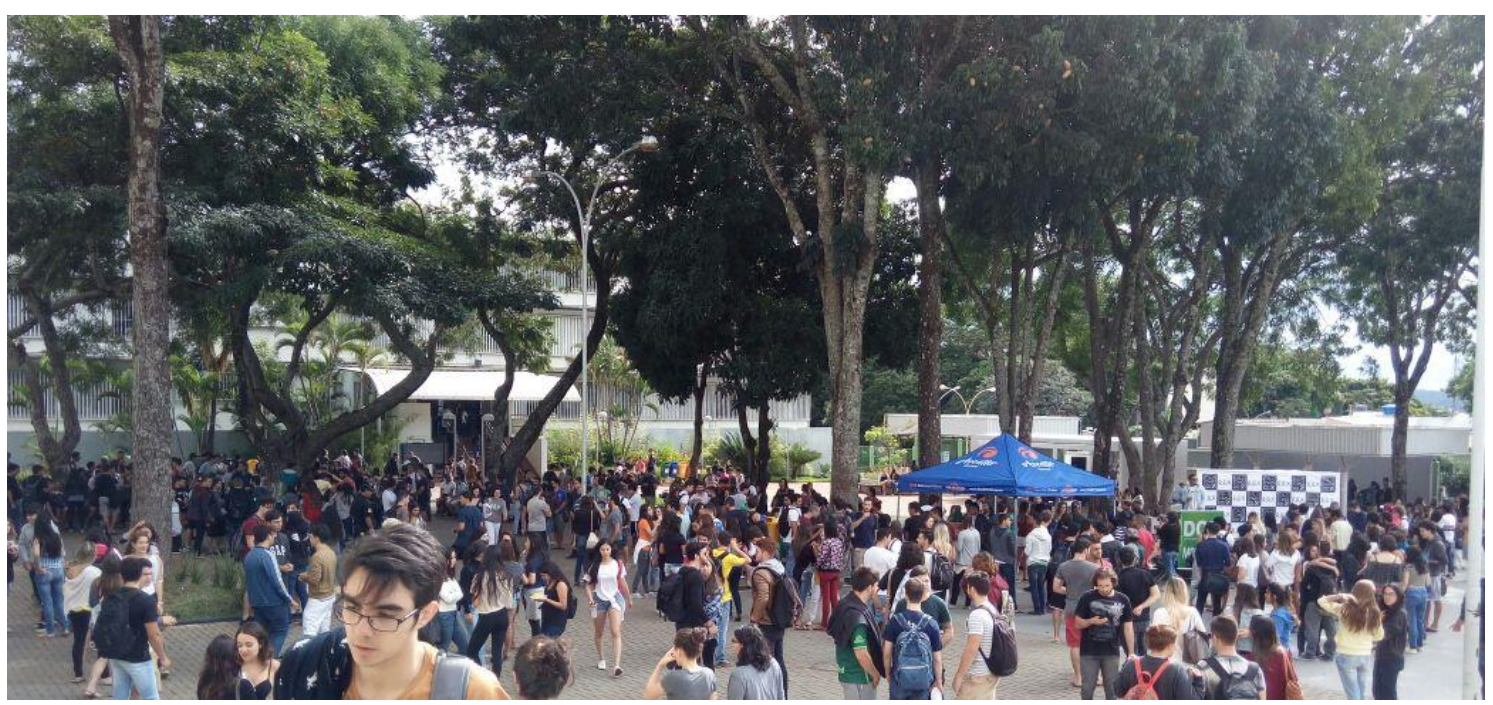

Figura 16: Ponto 8: Intensidade de fluxo: 


\section{Ponto 9}

O ponto 9 (Figura 17) abriga duas áreas de convivência: a primeira é a praça do Bloco 9 (à direita da figura 17), como é chamada, trata-se de um local de reunião de alunos, principalmente, dos cursos de saúde; a segunda, o Baião (Figura 18), nome dado devido a copiadora Baião, é um local voltado para a alimentação, por causa da existência de uma lanchonete. Ambas as áreas possuem fluxo intenso, porém menor que o fluxo do "Bosque" e do "Píer".

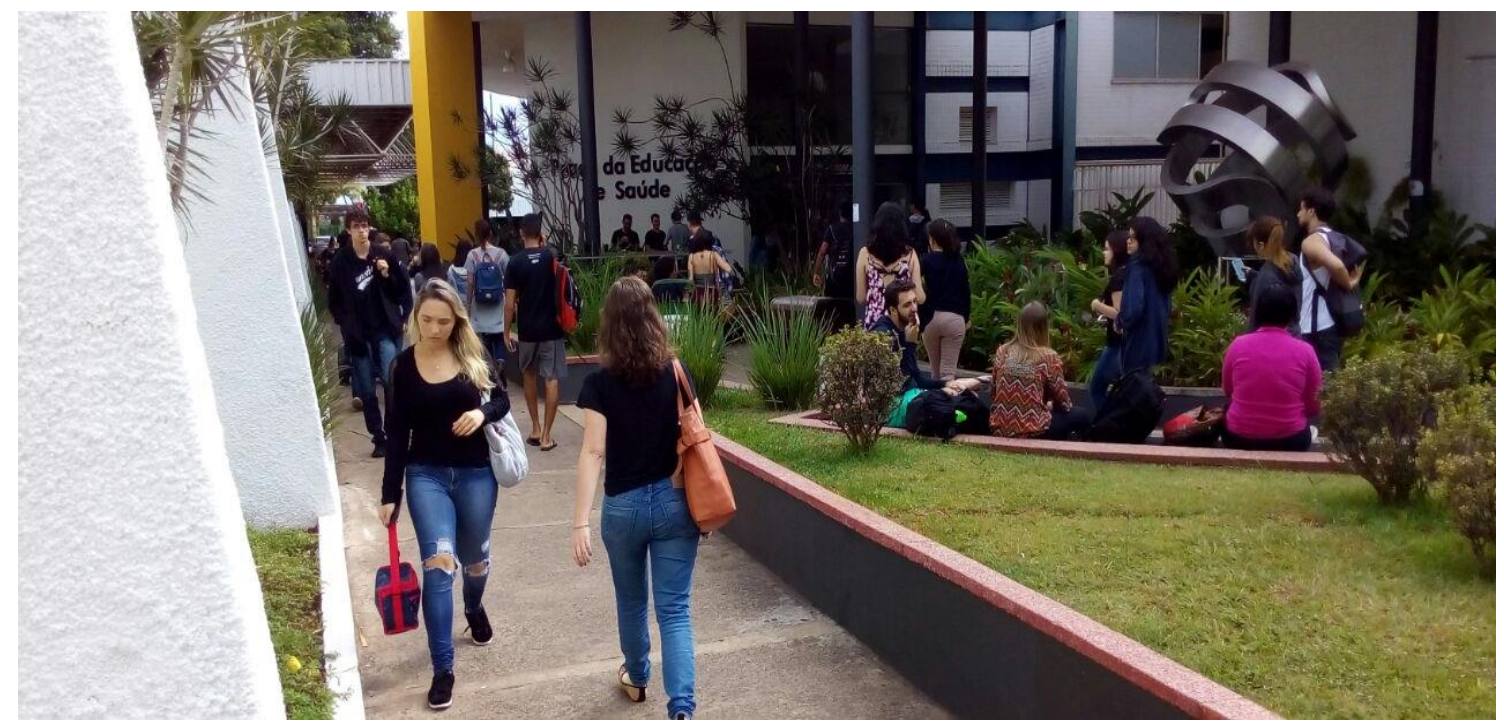

Figura 17: Ponto 9: Intensidade de fluxo:

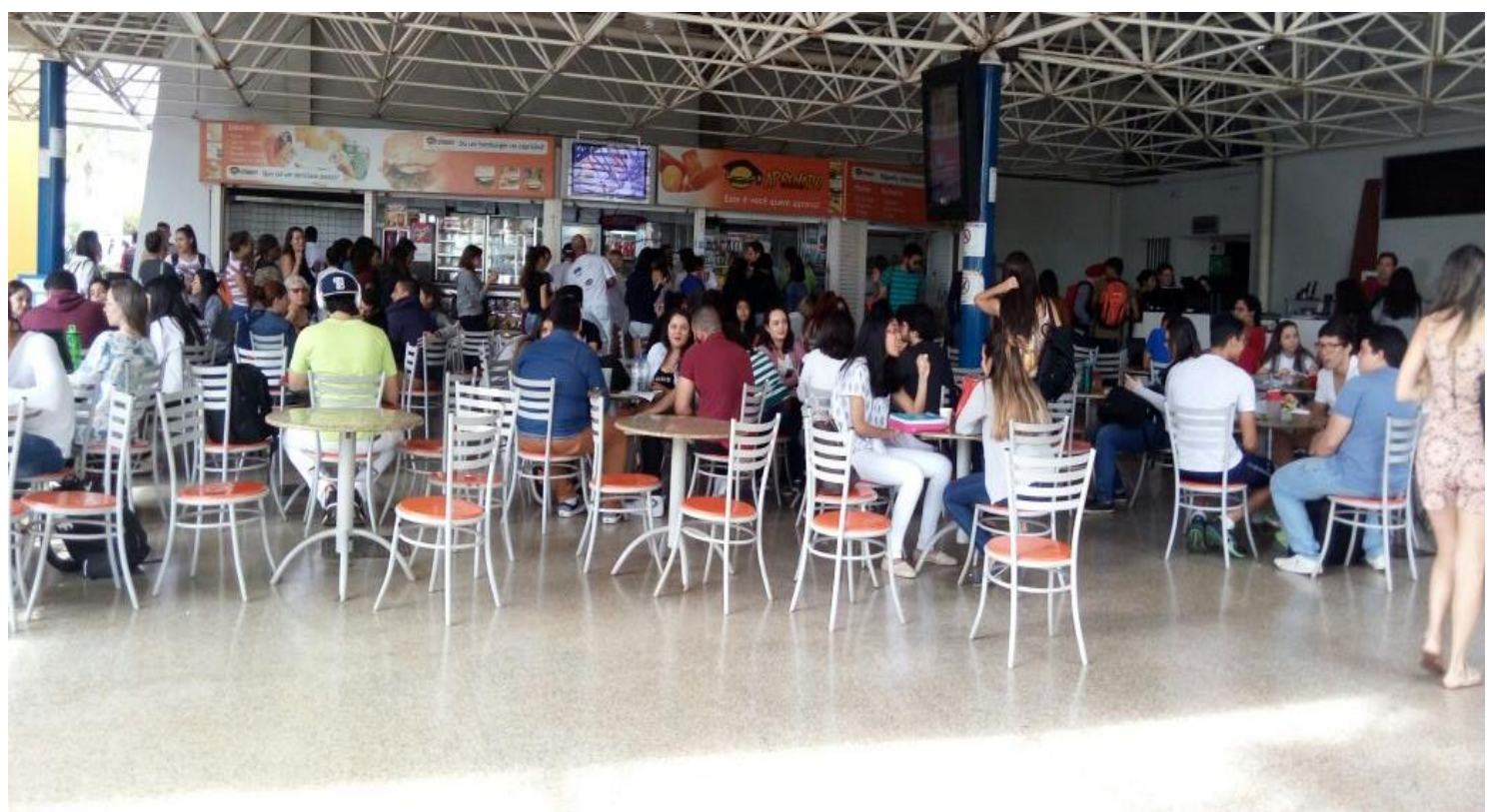

Figura 18: Ponto 9: Intensidade de fluxo: 


\section{Ponto 10}

O ponto 10 (Figuras 19 e 20) assemelha-se aos pontos 3 e 4 , pois é um corredor a céu aberto que conecta o Baião (lanchonete) e o Bloco 10 (figura 4). A intensidade é fraca devido ao uso, exclusivo de passagem. Neste ponto, encontra-se o terceiro estacionamento interno e privativo, uma área arborizada e agradável que está abrigando os veículos durante todo o dia.

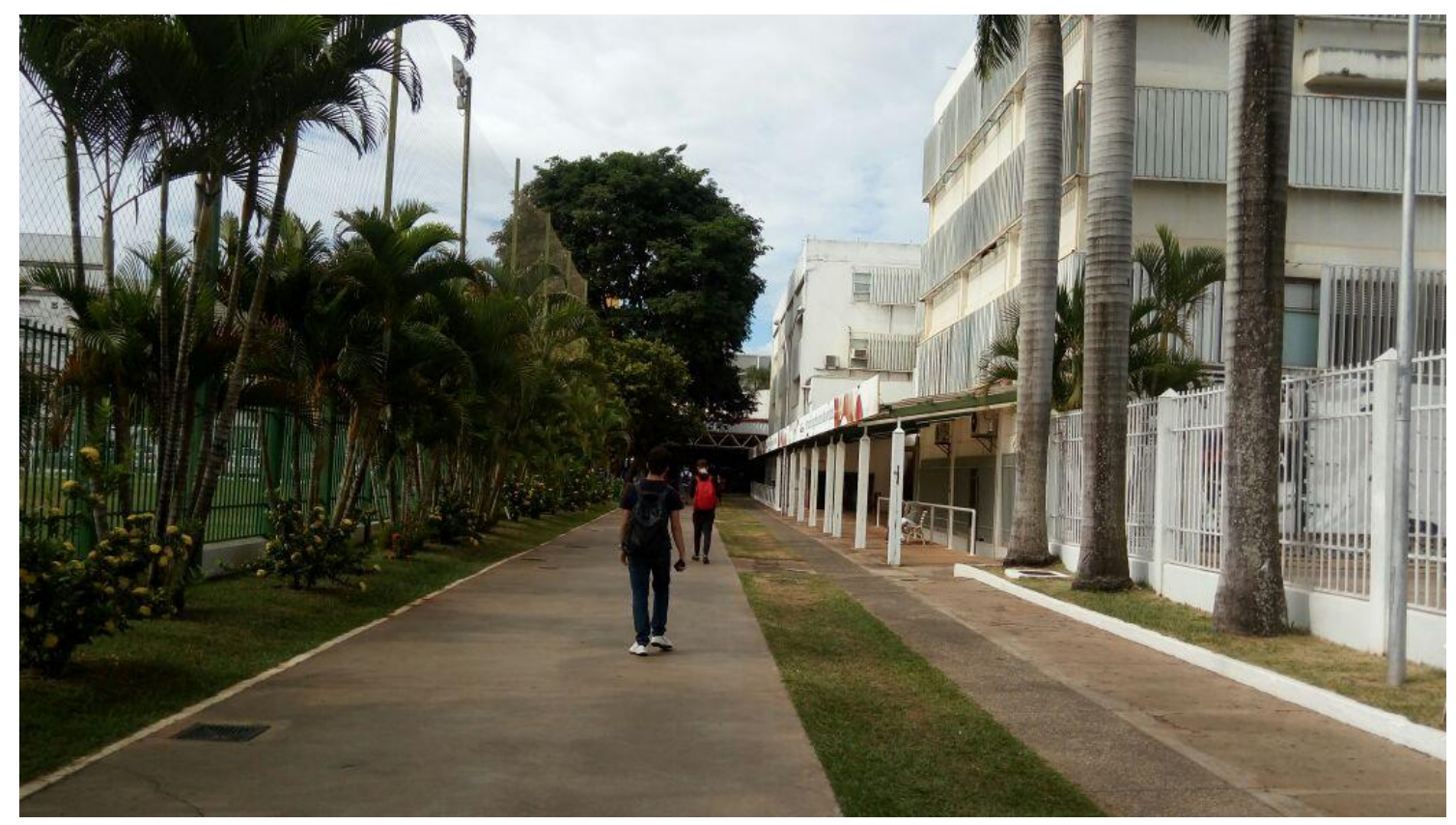

Figura 19: Ponto 10: Intensidade de fluxo:

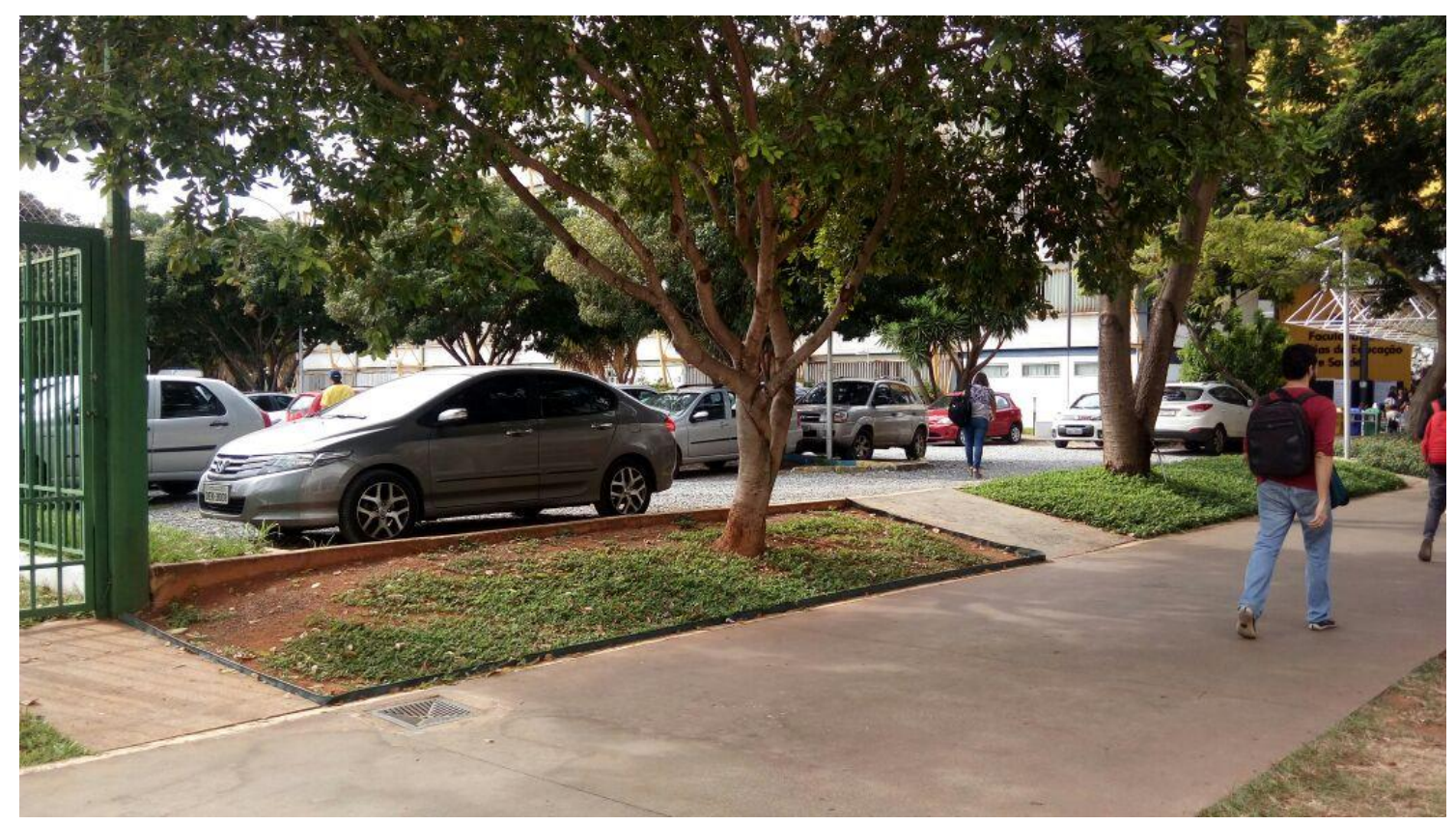

Figura 20: Ponto 10 -Estacionamento: Intensidade de fluxo: 
No ponto 10 (Figura 21) também existe uma área chamada de arquibancada, é uma área em que os estudantes costumam sentar e fazer as refeições e socializar, apesar de ser um local desconfortável, alguns alunos passam o tempo ali.

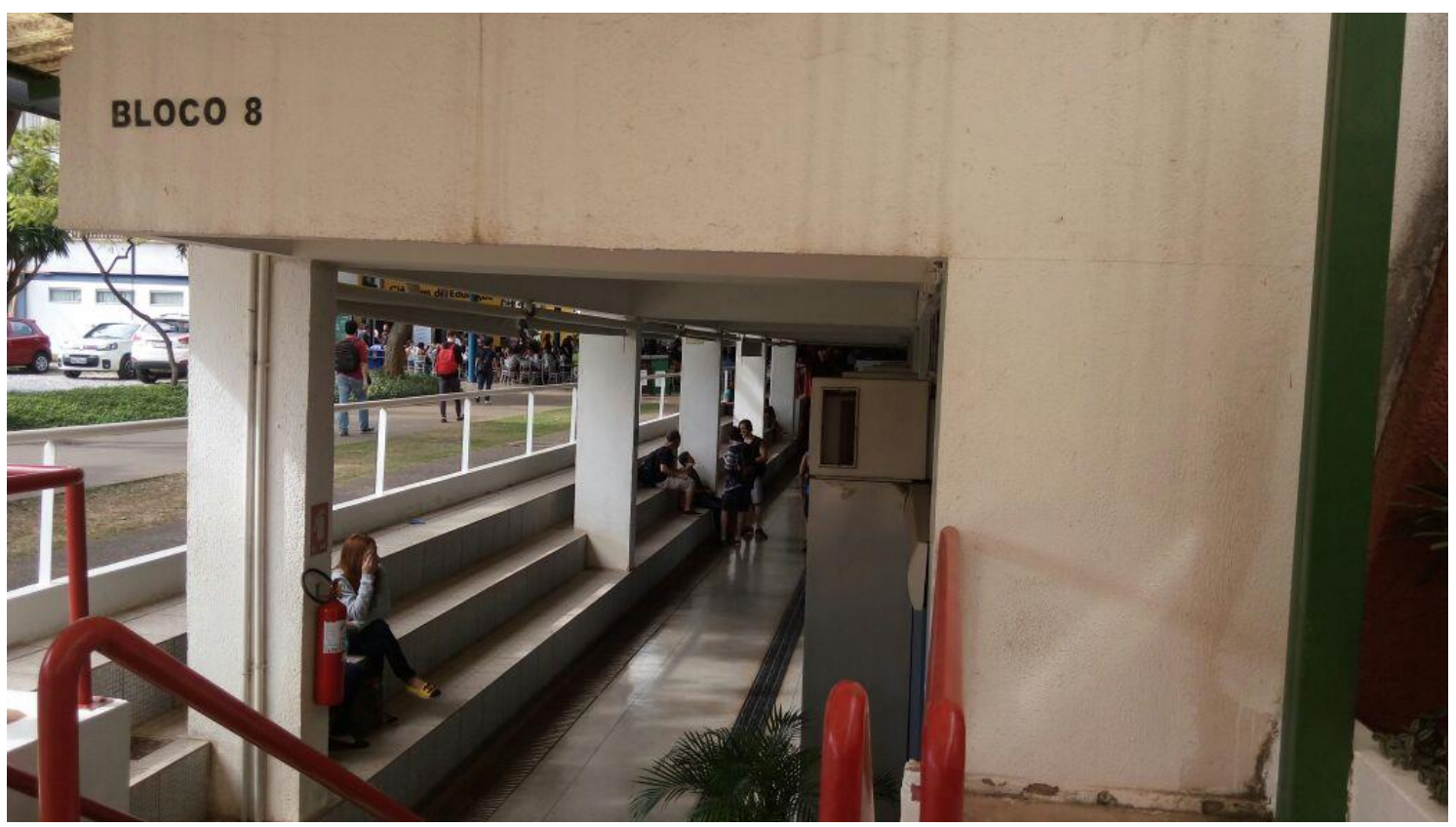

Figura 21: Ponto 10: Intensidade de fluxo:

\section{Ponto 11}

O ponto 11 (Figura 22) é uma área que possui uma pequena lanchonete, o DCE da institução e alguns jogos e, costuma ficar cheio durante todo o dia, pois muitos estudantes passam o tempo livre jogando ping-pong, sinuca ou pebolim. 


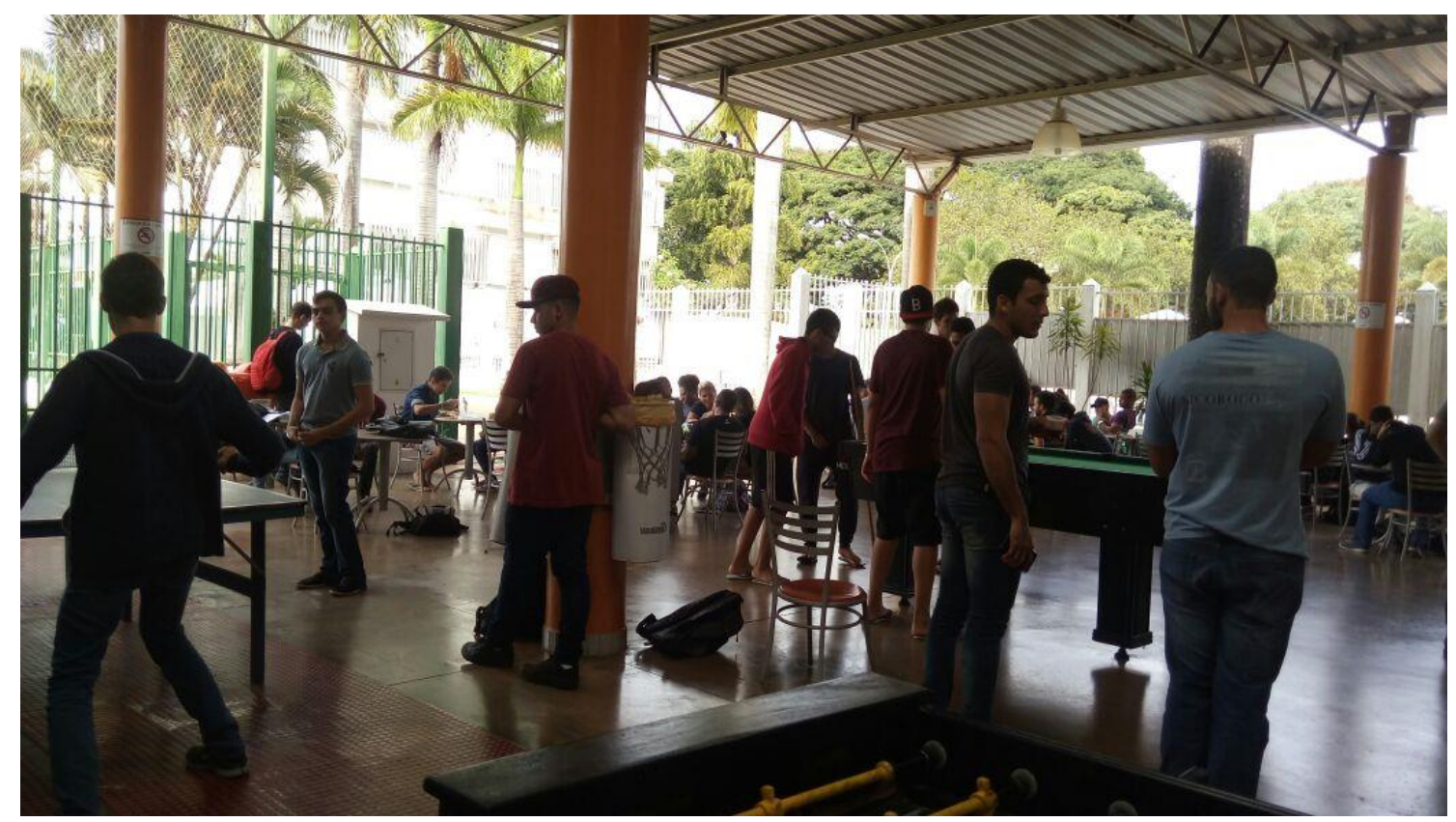

Figura 22: Ponto 11: Intensidade de fluxo:

\subsection{Questionários}

Os questionários (ver anexo I) foram aplicados em um dia de semana comum e a quantidade distribuída foi medida de acordo com a intesidade de cada área aberta, por exemplo, o "Bosque" e o "Píer" foram os locais com maior número de questionários, em contrapartida, os estacionamentos tiveram quase nenhum, pois, segundo as contagens, haviam poucas pessoas ali.

Os 300 questionários foram aplicados nos três turnos (manhã, tarde e noite) e em todas as áreas abertas descritas no item 4.2 (contagem de pessoas por meio de fotos). Diversos grupos participaram, desde estudantes até funcionários da instituição, dessa forma, pode-se obter resultados mais precisos para a análise.

Para compeender a questão dissertativa do questionário (Ver anexo I, questão 17), foi utilizado um mecanismo de análise (Tabela 1) com base nos estudos de Feitosa (2010), que classifica as respostas mais frequentes em uma tabela, a fim de se obter uma visão clara a respeito da das opniões acerca do assunto, dessa forma, as justificativas da Questão 17 (Ver anexo I) estão expostas na Tabela 1, com exemplos de verbalizações. 
Q. 17: Você acha que lugares abertos, com arborização e espaços para relaxar iriam melhorar o desempenho dos alunos? Por que?

\begin{tabular}{|c|c|}
\hline Mecanismos de justificação & justificativa \\
\hline Colaboração & $\begin{array}{l}\text { "Por que ambientes agradáveis ajudam a relaxar e } \\
\text { diminuem o stress dos alunos." }\end{array}$ \\
\hline Contribuição & $\begin{array}{l}\text { "Em um curso de criatividade, como o meu, você } \\
\text { precisa de um espaço de qualidade para poder criar." }\end{array}$ \\
\hline Carência & $\begin{array}{l}\text { "O espaço de estacionamento é desperdiçado, } \\
\text { poderiam usar esse espaço para os alunos." }\end{array}$ \\
\hline Indiferença & $\begin{array}{l}\text { "Não faria diferença, pois quando a pessoa quer, ela } \\
\text { estuda em qualquer lugar." }\end{array}$ \\
\hline Transferência do problema & "Quem quer estudar vai para a biblioteca." \\
\hline Deslocamento de Culpa & $\begin{array}{l}\text { "Acho que o desempenho não mudaria, deixaria os } \\
\text { alunos mais folgados, o povo mataria mais aula." }\end{array}$ \\
\hline
\end{tabular}

Tabela 1: Exemplos de justificativas da questão dissertativa do questionário.

A Tabela 1 mostra diferentes opiniões acerca do tema de "espaços abertos dentro da universidade", de modo geral, foi observado que alguns estudantes não analisam o espaço de forma sensível, pois muitas respostas foram semelhantes aos mecanismos de indiferença, transferência do problema, do deslocamento da culpa, citados na Tabela 1, e, infelizmente, essa forma de pensamento leva-os a acreditar que o desempenho estudantil é resumido apenas a locais de estudo, quando, na verdade é uma série de quesitos.

Espaços de qualidade podem influenciar positivamente a vida das pessoas, aqueles que possuem áreas arborizadas, ventilação natural e incidência solar tem a capacidade de elevar a saúde do ser humano, principalmente se aliar a mobiliários urbanos, comércio e lazer, esses espaços ganham vida e tornam-se agradáveis de se estar (GEHL, 2010).

Porém, é necessário analisar essa questão sob o olhar das pessoas que permanecem mais tempo no campus, pois, geralmente, são estes os que mais reclamam da falta de espaço. Em contrapartida, aqueles que possuem veículo próprio e tem a possibilidade de voltar para a casa após as aulas, dificilmente acham que a falta de espaços de qualidade interfere na rotina diária.

Essa falta de sensibilidade do espaço e a incoerência entre as respostas pôde ser observada na relação entre as questões 12 e 13 (Gráficos 1 e 2), do 
questionário. Para análises mais profundas foram comparados os locais onde moram e meio o de transporte utilizados para chegarem até a universidade.

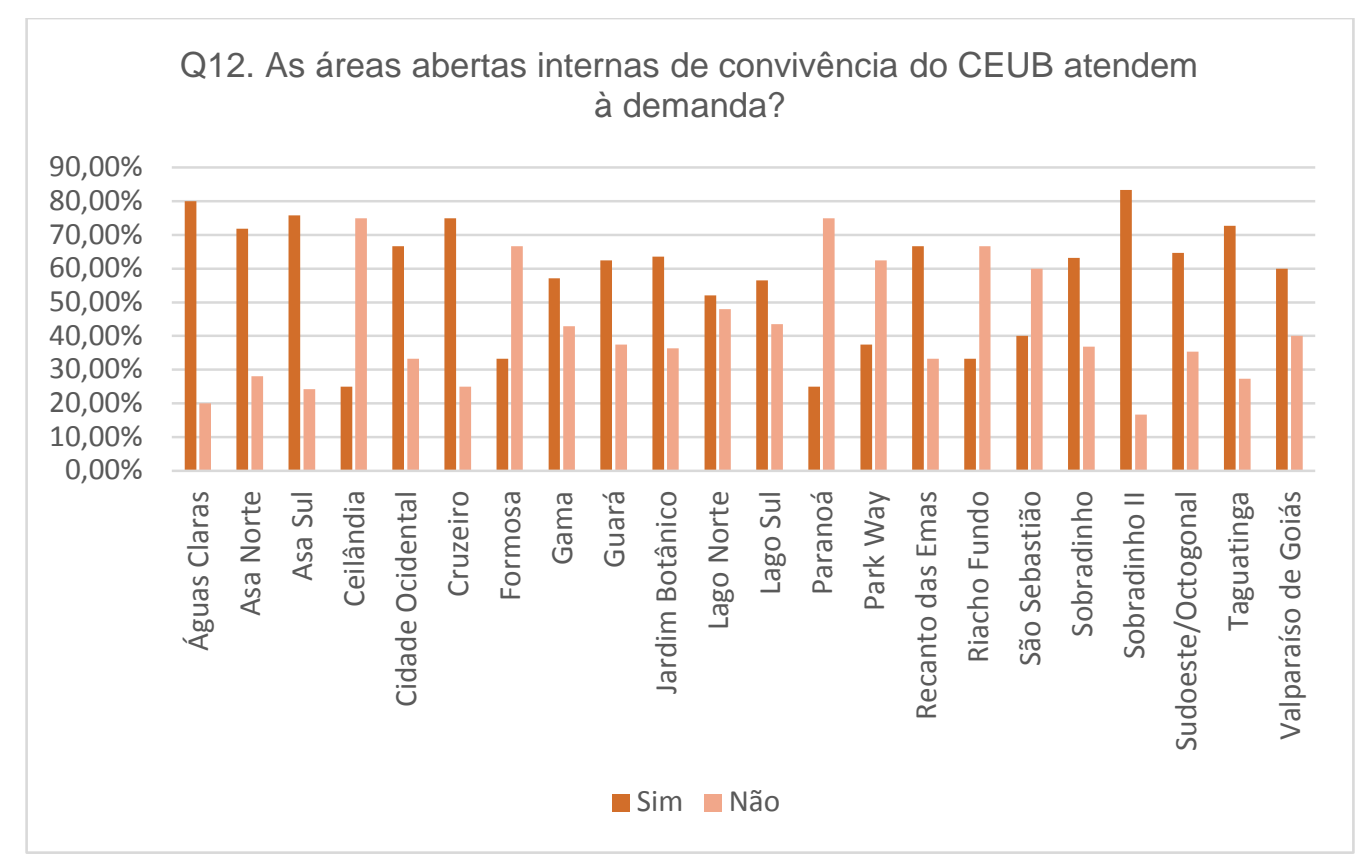

Gráfico 1: Questão doze do questionário cruzada com o local de moradia.

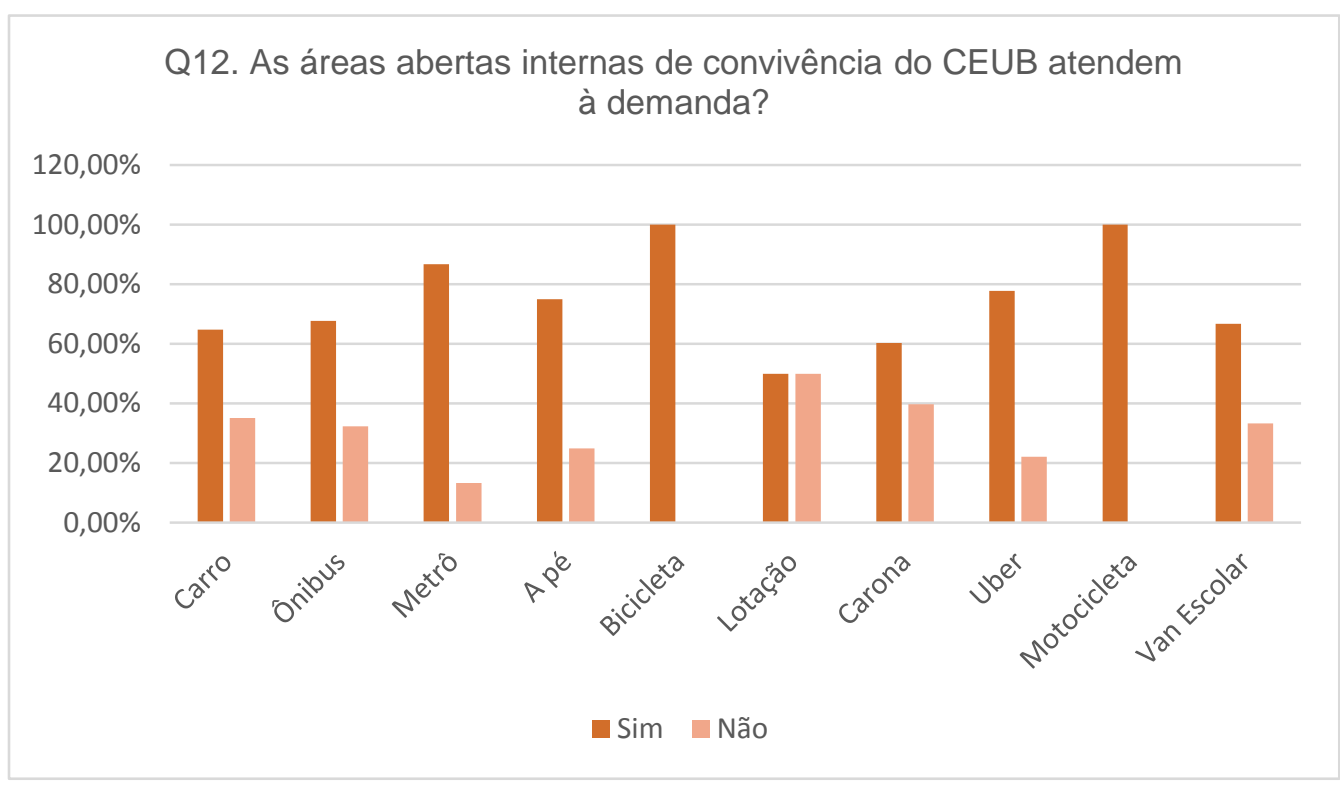

Gráfico 2: Questão doze do questionário cruzada com o meio de transporte utilizado.

As respostas apontaram majoritariamente que os usuários do UniCEUB acreditam que as áreas abertas internas de convivência (Figura 8) atendem à demanda de alunos, porém, esse dado contradiz as reclamações dos estudantes e funcionários que participaram dos grupos focais, sendo assim, 
para entender essa diferença, a questão em destaque precisou ser comparada com a pergunta 13 (Gráficos 3 e 4) para uma análise mais profunda.

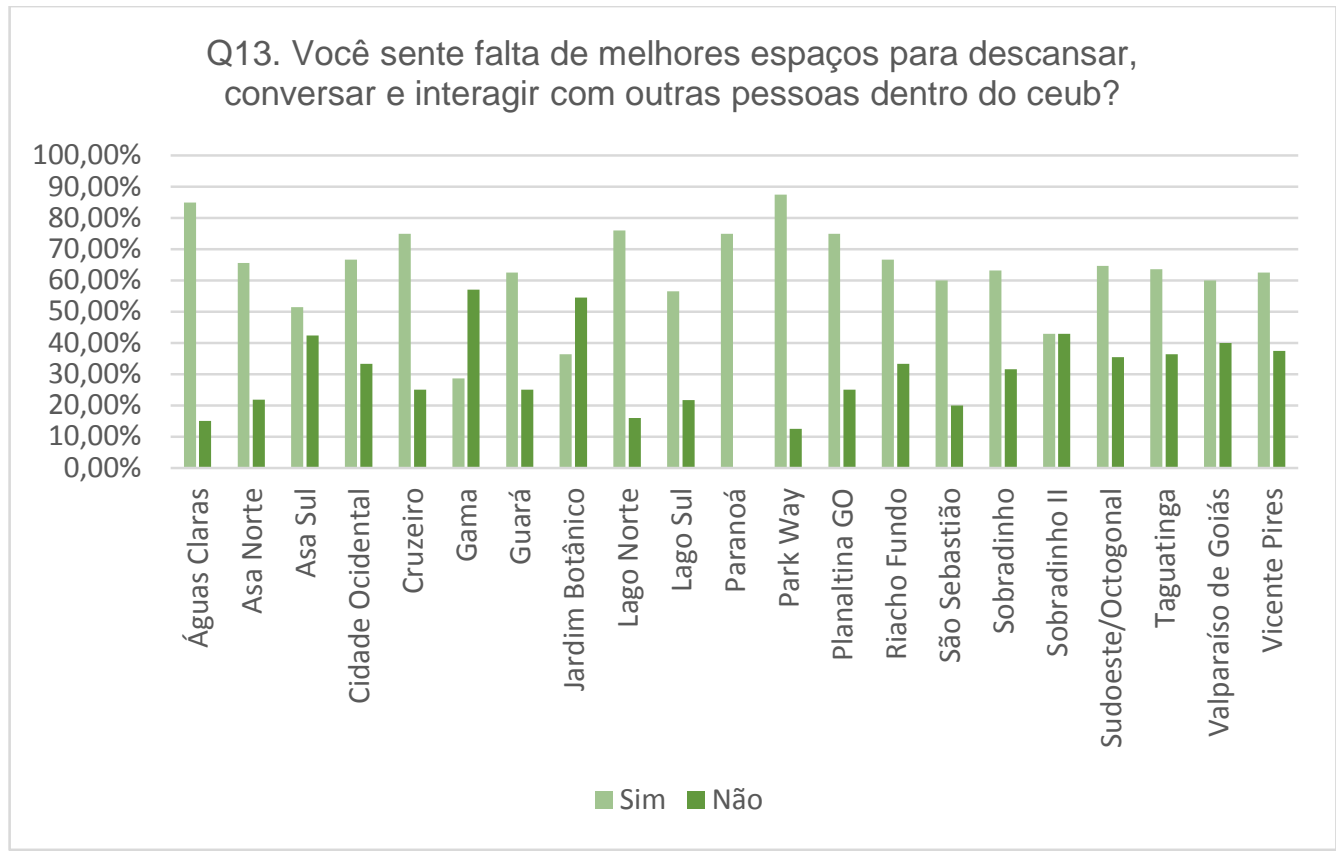

Gráfico 3: Questão treze do questionário cruzada com o local de moradia.

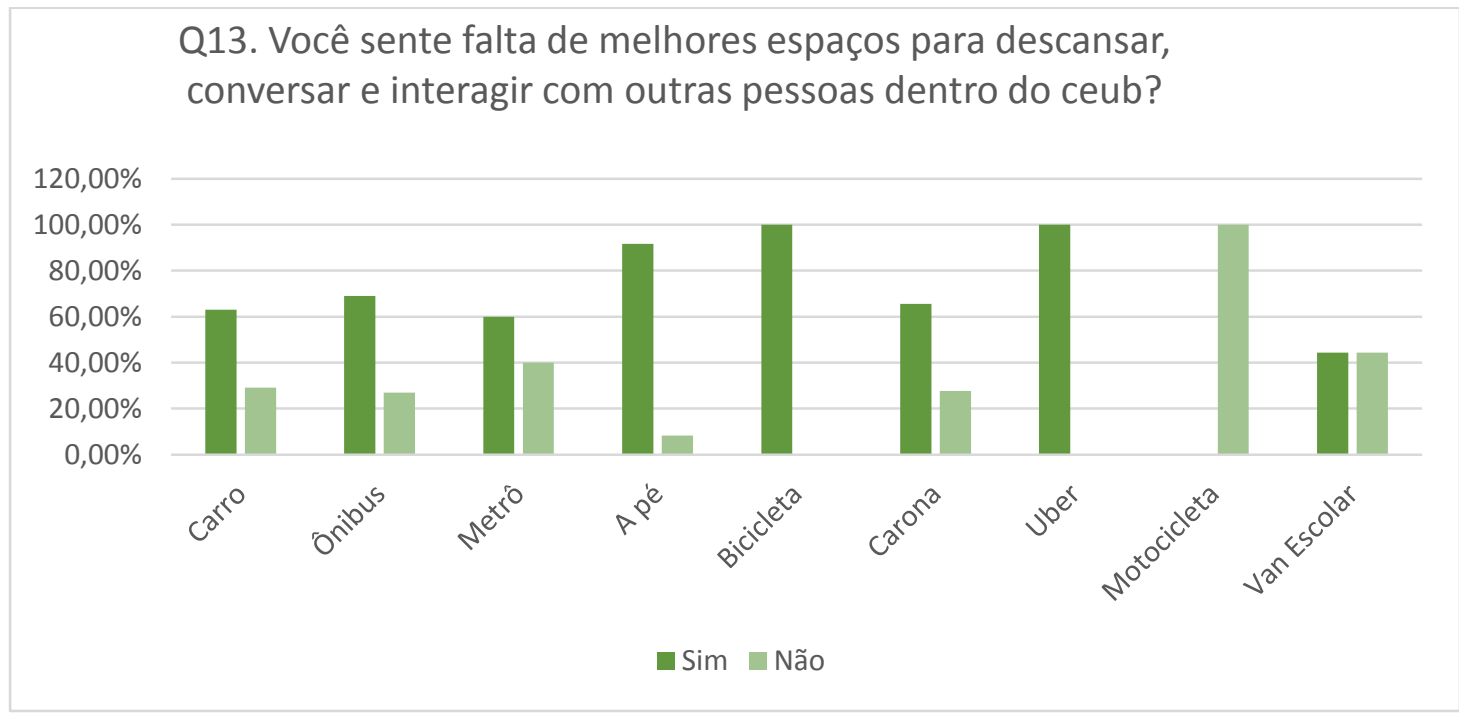

Gráfico 4: Questão treze do questionário cruzada com o meio de transporte utilizado.

Contraditoriamente, a maioria dos inquiridos sente falta de melhores espaços para descansar, conversar e interagir com outras pessoas dentro da universidade, este dado mostra que apesar dos estudantes carecerem desses espaços, a maioria não consegue diferenciar a falta de espaços de qualidade da demanda de estudantes.

Já a pergunta número 15 (Gráficos 5 e 6), teve como objetivo captar a percepção das pessoas em relação aos espaços que frequentam. A maioria não acredita que os estacionamentos internos privativos aos professores 
interferem no fluxo do pedestre, esta resposta já era esperada, visto que os entrevistados nos grupos focais tiveram a mesma impressão.

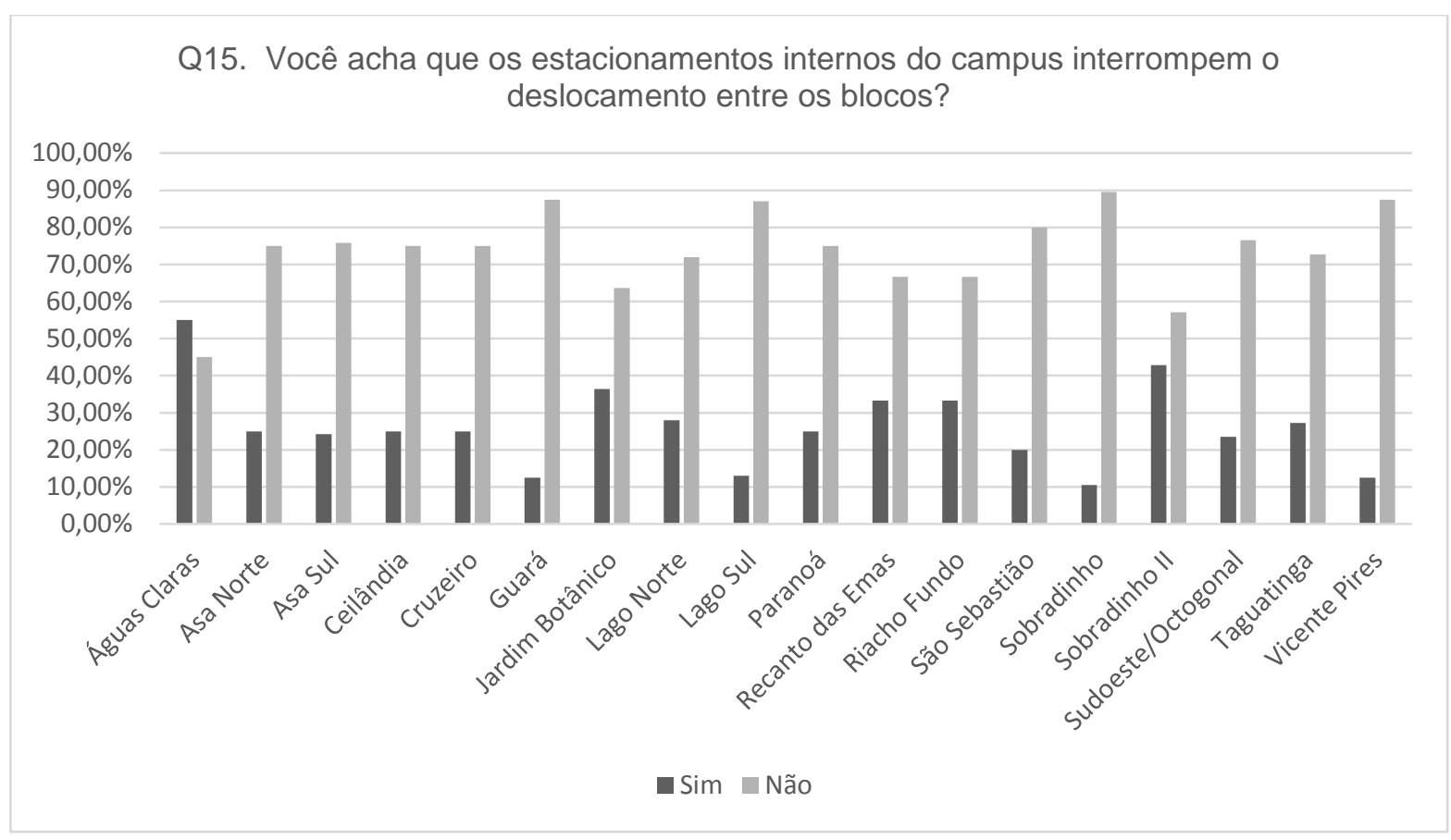

Gráfico 5: Questão quinze do questionário cruzada com o local de moradia.

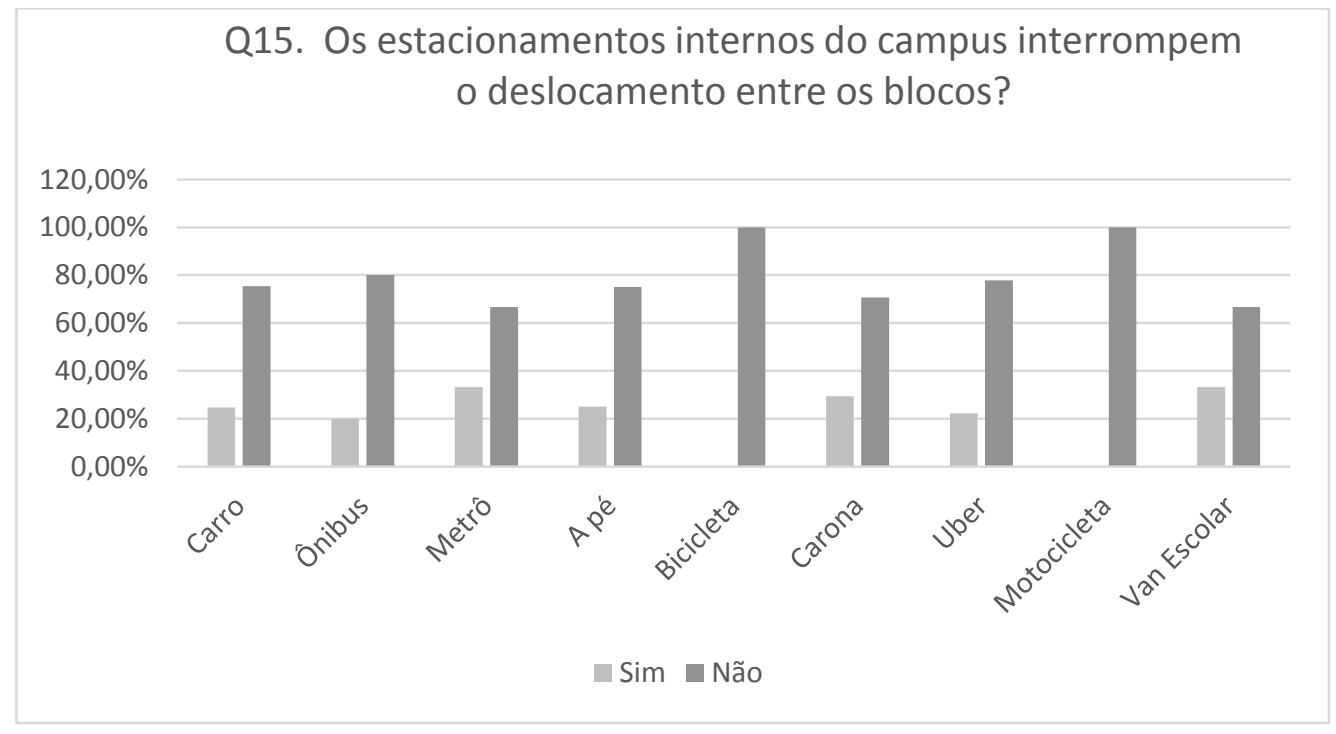

Gráfico 6: Questão quinze do questionário cruzada com o meio de transporte utilizado.

Apesar das respostas, os estacionamentos internos privativos, além de interromperem o fluxo do deslocamento entre os blocos, cortam o caminho do pedestre, principalmente os de número 1 e 2 (Figura 23), conforme apresentado na Figura 15 em que há uma fita que é colocada para que os pedestres não adentrem a área dos veículos. 


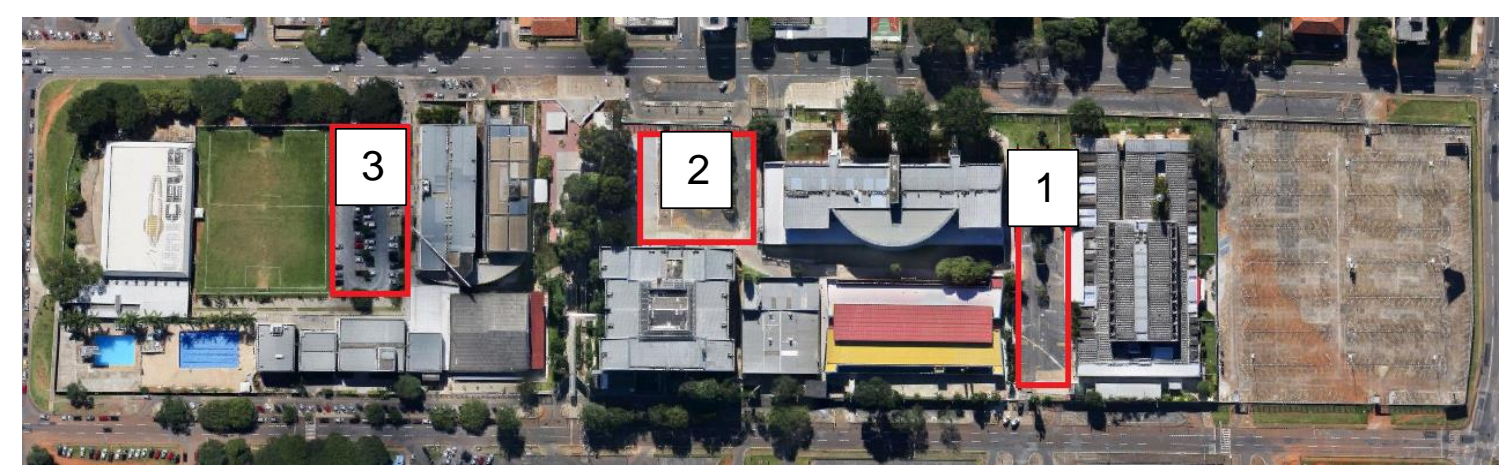

Figura 23: Estacionamentos internos interrompem o fluxo dos pedestres.

O estacionamento 1 (Figura 24), tornou-se um meio de ligação entre os demais blocos e o Bloco 01, os pedestres já se acostumaram tanto a passar entre os carros e desviar dos automóveis que se tornou algo natural, isso mostra que já é uma realidade vivenciada por muitos na cidade, pois a maioria não nota que existe um estacionamento conectando os prédios.

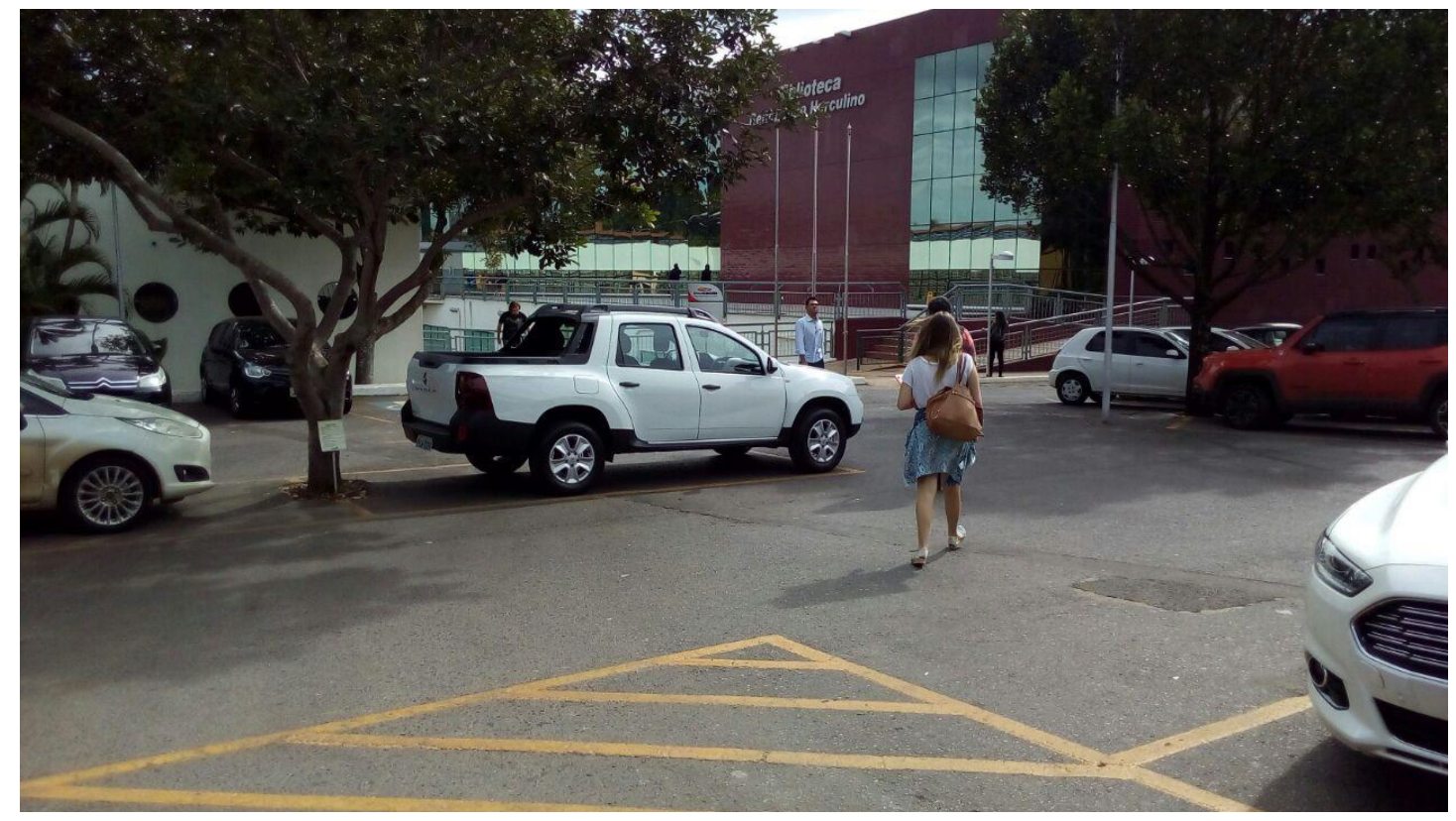

Figura 24: Pedestres precisam desviar dos carros no estacionamento 1.

O estacionamento 2 (Figura 25) tornou-se o meio de acesso para o Bloco $02 \mathrm{e}$ para a Biblioteca e está localizado ao lado do "Bosque", o que gera um grande contraste entre os dois espaços. Um entrevistado foi interrogado no "Bosque", e ao ser questionado sobre os estacionamentos, ficou surpreso ao saber que existia um ao lado, ele argumentou que nunca tinha notado o estacionamento, apesar de passar quase todos os dias por ele e já frequentar a instituição há alguns anos. Isso mostra o quanto as áreas destinadas aos veículos são comuns em qualquer lugar da cidade, visto que até tornam-se interceptáveis no dia a dia. 


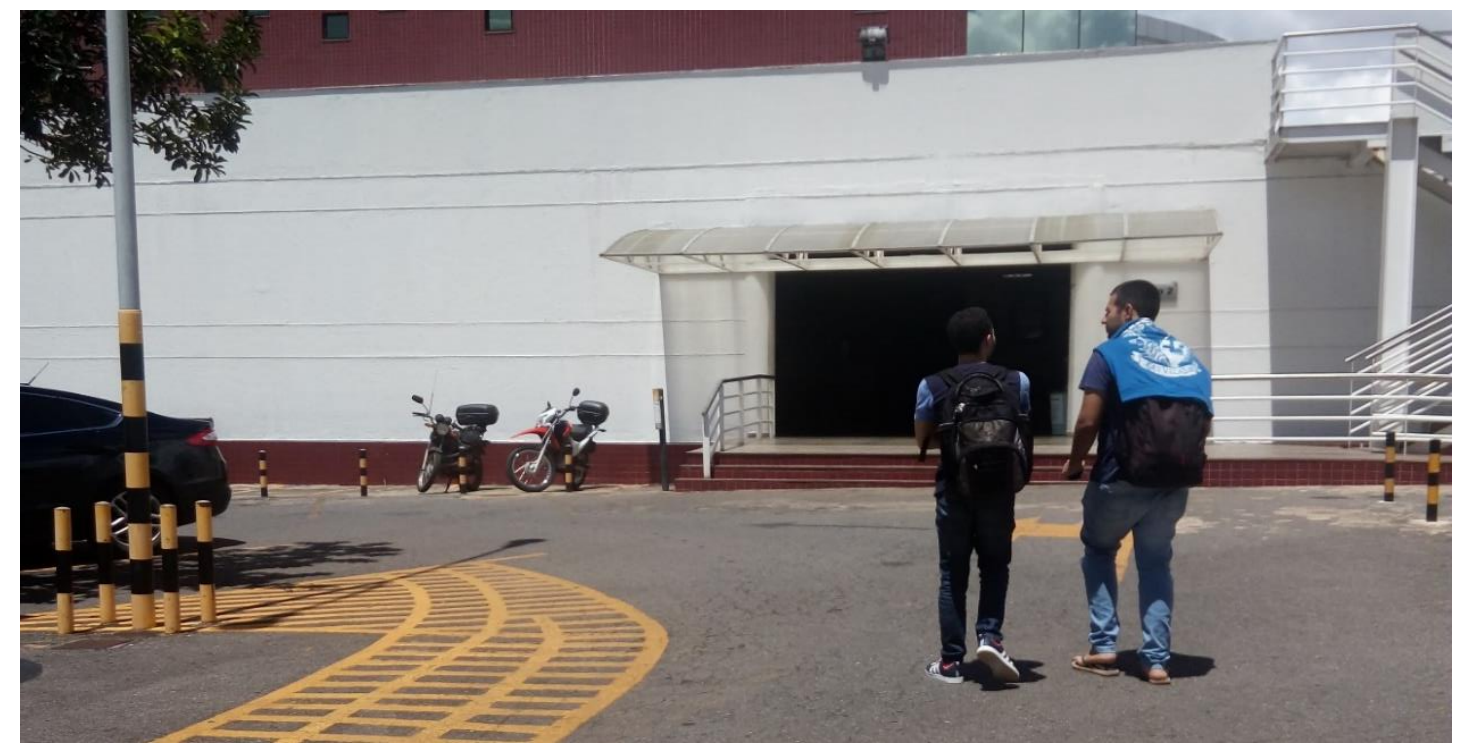

Figura 25: Estacionamento é meio de acesso aos blocos e interrompe o fluxo dos pedestres.

As imagens podem comprovar que os estudantes e funcionários já se acostumaram com os estacionamentos internos e não percebem a interferência que ele causa ao caminhar pela universidade.

Aliando as respostas obtidas na questão 16 (Gráfico 7 e 8) juntamente com os grupos focais, pode-se concluir que os alunos e funcionários anseiam por novas áreas de convivência de qualidade e os estacionamentos internos são apontados como possíveis soluções para serem utilizados para tais. Apesar das dúvidas e do medo em relação à reação que os professores teriam ao precisar estacionar em outro lugar, a maioria concorda que seria interessante desenvolver áreas mais vivas e utilitárias.

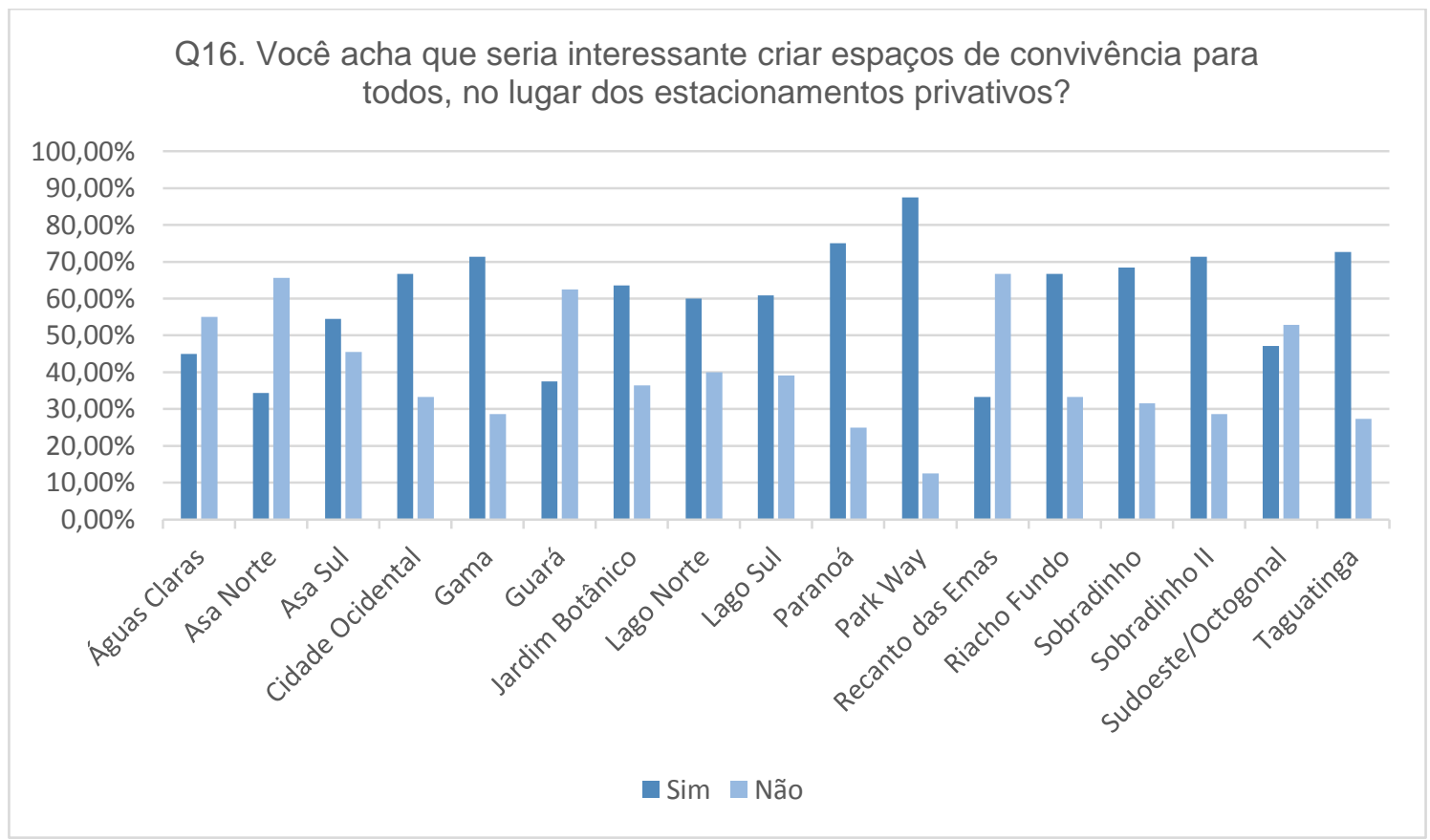

Gráfico 7: Questão dezesseis do questionário cruzada com o local de moradia. 


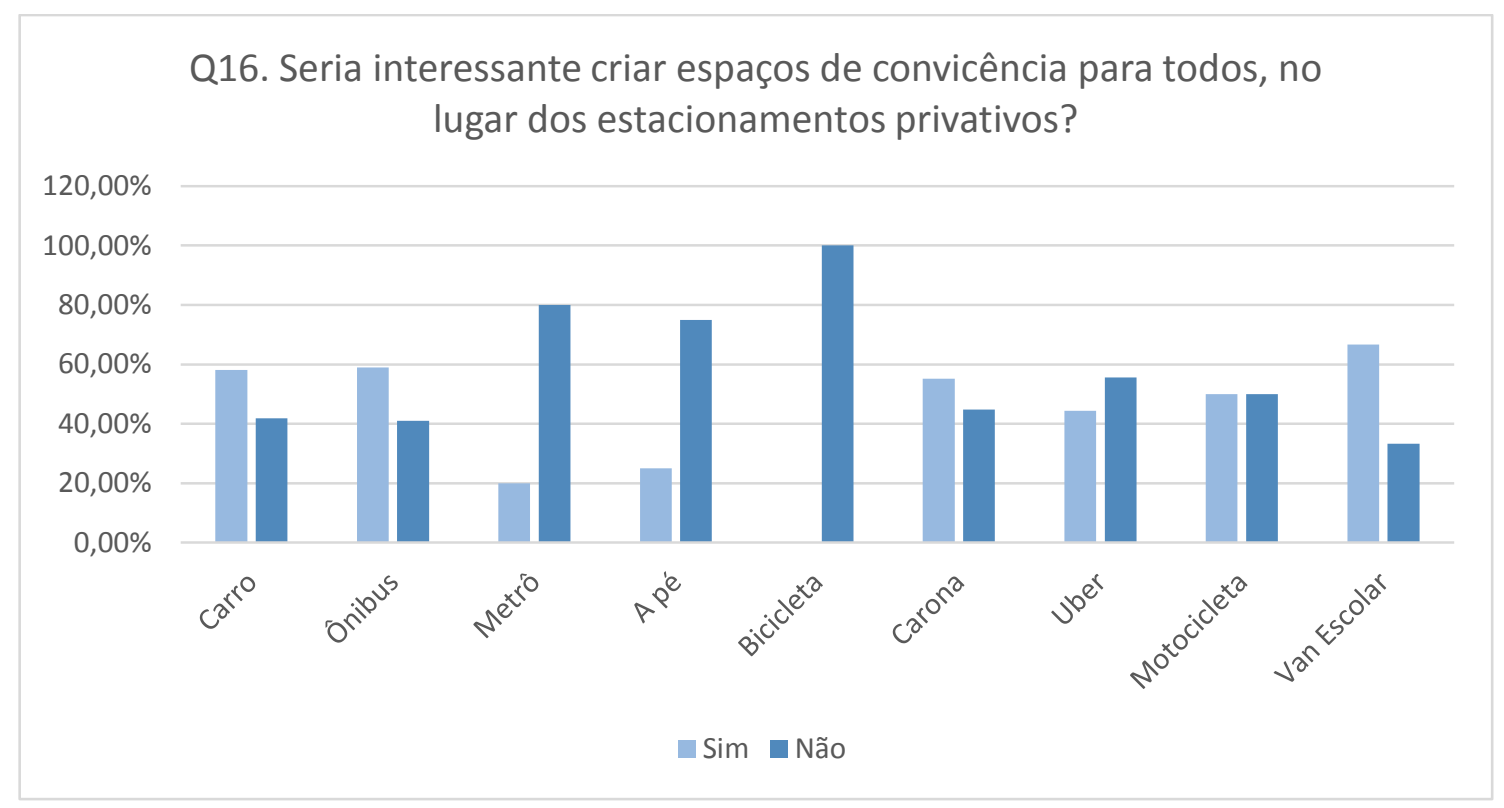

Gráfico 8: Questão dezesseis do questionário cruzada com o meio de transporte utilizado.

\section{Considerações finais}

\subsection{Conclusões}

Em Brasília, costuma-se alegar que as pessoas possuem "cabeça, tronco e rodas", a citação decorre devido o uso excessivo de veículo para locomoção diária, fato decorrente do projeto urbanístico da cidade. Nesse cenário, 0 automóvel logo assumiu gradativamente a extensão do ambiente doméstico, atribuindo valor, status e luxo aos seus proprietários (BAUDRILLARD,1989). Por consequência, a demanda por estacionamentos aumentou e tornou as áreas mortas uma cena cotidiana do brasiliense.

Em consequência do uso demasiado do automóvel, foi gerado um fluxo de pessoas que moram distantes do Plano Piloto e, consequentemente, precisam passar o dia na universidade, com raras oportunidades de voltar para casa durante dia. Essa maioria sofre com os efeitos colaterais gerados por esse sistema, pois precisam de uma estrutura que, muitas vezes, faltam para atender as necessidades diárias como: vestiários, refeitórios, bicicletários e áreas de descanso e, infelizmente, foi constatado que o UniCEUB carece dessas áreas, tanto para estudantes, quanto para funcionários.

Foi constatado, com a aplicação dos grupos focais e dos questionários, que a supervalorização do carro, em Brasília, é um problema sutil, por isso poucos enxergam as consequências, mas todos sentem os sintomas de uma cidade voltada para o automóvel. Porém, o Centro Universitário de Brasília é considerado um Polo Gerador de Viagem (PGV - Grande empreendimento que atrai e fera muitas viagens diárias), portanto, a instituição deveria investir em espaços para realizar as atividades necessárias, opcionais e sociais, todas com qualidade (GEHL, 2010).

Pode-se concluir que a instituição não utiliza bem as áreas existentes, visto que possui espaços para a inclusão dos itens supracitados, porém são utilizados 
como estacionamentos internos, por exemplo. Tal fato vêm prejudicando os alunos e funcionários da instituição, pois são grandes áreas, localizadas estrategicamente que poderiam ser reformuladas para melhor utilização do local.

Além desses pontos, os resultados também mostraram que a universidade possui uma ligação com o estudo de Magnani, a semelhança encontrada é referente à disposição dos edifícios da universidade com o tecido urbano de Brasília, uma vez que os blocos são segregados por cursos, os estudantes tendem ficar vinculados majoritariamente ao seu "pedaço", dessa forma, existe uma analogia encontrada entre os blocos da instituição e os "pedaços" encontrados na cidade.

A delimitação física dos prédios faz com que o funcionário ou estudante fique vinculado ao bloco em que atua, de forma simbólica, assim, foi possível classificar os usuários em "fora ou dentro do bloco" ou, como o autor aborda, "fora ou dentro do pedaço". Da mesma forma, as ruas da cidade foram comparadas com os espaços abertos da instituição, pois é onde ocorre, eventualmente, funções e atividades educacionais, desde feiras de empreendedorismo, palco de apresentações e discussões e debates, ou seja, da mesma forma que ocorre nas cidades, as "ruas" das universidades são responsáveis pela vivacidade e pelos principais meios de encontro.

Nesse contexto, a universidade em questão replica o comportamento de Brasília (Figuras 26 e 27); de forma inconsciente, uma vez que o espaço urbano é grande demais e nada convidativo, os caminhos são longos, retos e desinteressantes e os carros estacionados impedem caminhadas agradáveis no resto da cidade (GEHL, 2010). Portanto, a semelhança entre a cidade e a universidade em questão (Figuras 26 e 27) está vinculada ao fato de colocar o pedestre como segundo plano.

Portanto, partindo dos resultados obtidos, constatou-se que a universidade deve ser vista como uma cidade em escala micro, pois em ambas é encontrado diversidade de pessoas, cultura e pensamento, assim, de acordo com os estudos de Jane Jacobs, o campus deve estimular a existência de espaços que costurem e unam a universidade, proporcionando vida e o inter-relacionamento dos "pedaços". 


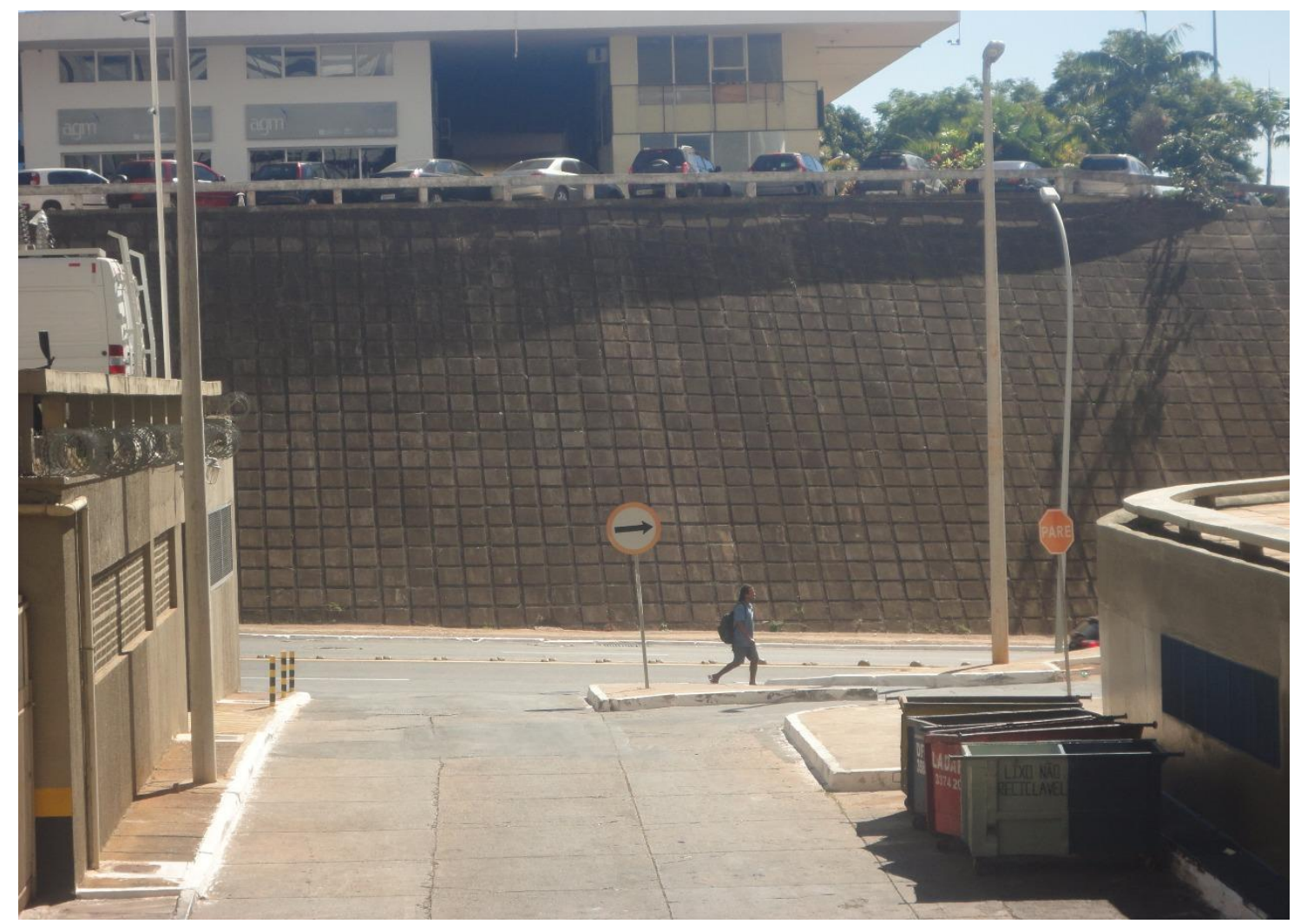

Figura 26: Pedestre em Brasília. 


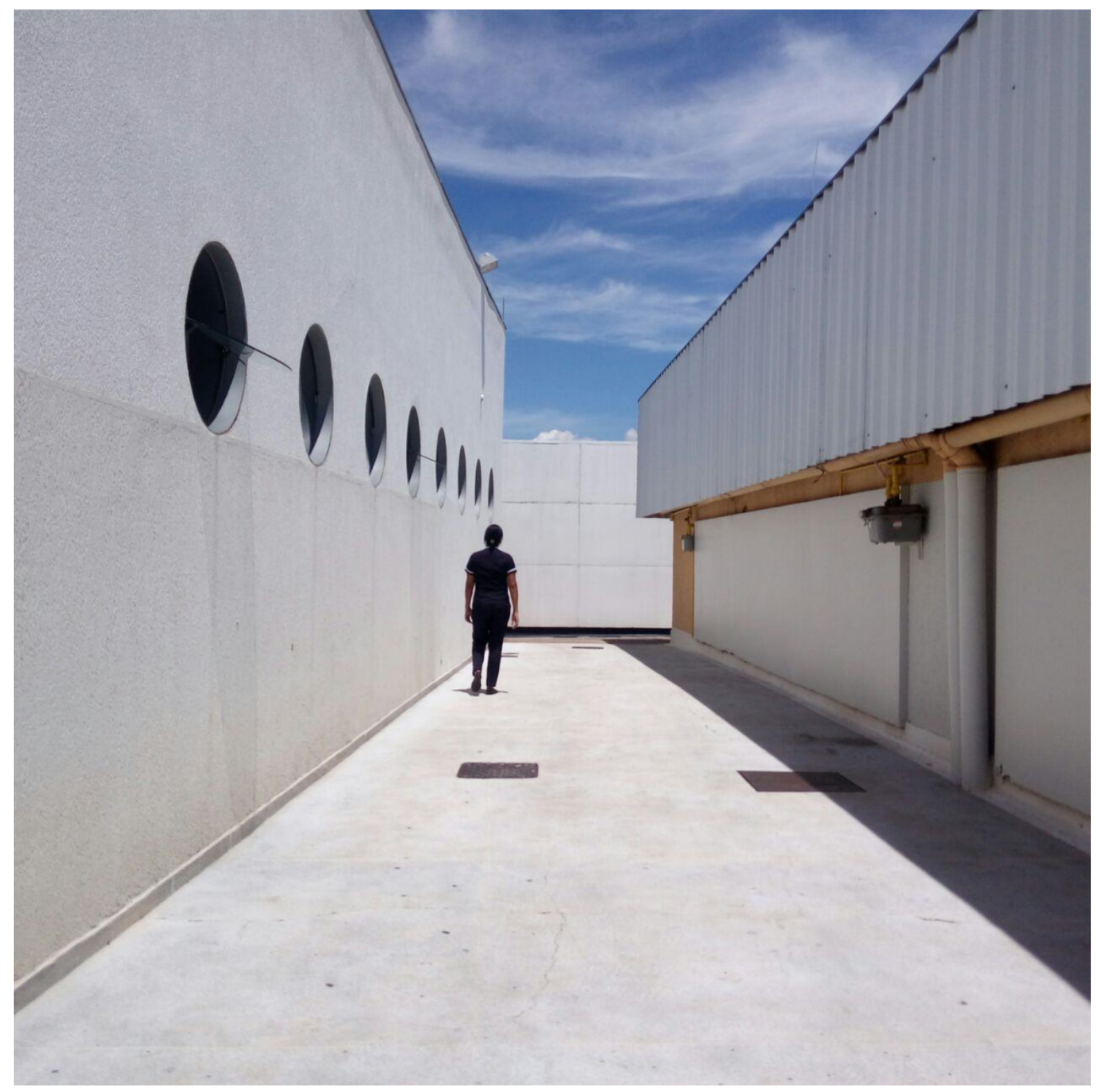

Figura 27: Pedestre em uma instituição particular.

\subsection{Recomendações}

Recomenda-se que haja a aplicação de novos questionários, tanto no campus, quanto no Espaço Aluno (Ferramenta online responsável pela comunicação entre a instituição, os professores e alunos) para abranger mais dados e estudar a poossibilidade de reprojetar os espaços sugeridos, bem como um refeitório estudantil, a criação de áreas de convivência e descanso no lugar dos estacionamentos internos privativos e em outros locais mortos onde não possuem função expecífica, visando o bem estar e a melhoria da qualidade de vida dos estudantes e funcionários.

É interessante que a pesquisa seja ampliada para outras instituições de ensino superior (públicas ou privadas), bem como no âmbito da cidade, para realizar estudos comparativos. 
Para complementar, recomenda-se que a instituição tome partido para diminuir a quantidade de veículos que desaguam no local, por meio de propagandas e pelo o incentivo do transporte solidário. Além disso, é necessário motivar o transporte não poluente, como a bicicleta, instalando bicicletários em todo 0 campus e dando visibilidade aos ciclistas da universidade.

\section{REFERÊNCIAS BIBLIOGRÁFICAS}

ARTIGAS, João Batista Vilanova. Caminhos da arquitetura; São Paulo: Cosac e Naify, 2004.

BAUDRILLARD, J. A sociedade de consumo. Portugal: Edições 70. 2008.

BRANDÃO, Ramon. O Automóvel no Brasil Entre 1955 e 1961: A Invenção de Novos Imaginários na Era JK. Juiz de Fora, 2011.

CHRISTILLEB, Federico Hernández. El Automovil Y Los Espacios Urbanos De America Latina. El Caso De La Ciudad De Mexico. Universidad Nacional Autónoma de México.

FEITOSA, Zuleide Oliveira. Competição por Espaço em Estacionamento Público: Invasão, Reações e Justificativas Diante de Vagas Reservadas. Brasília, 2010.

GEHL, JAN. Cidades Para Pessoas. Perspectiva. Rio de Janeiro. 2010.

JACOBS, JANE. A Morte e Vida de Grandes Cidades. Martins Fontes, São Paulo, 2000.

LEME, Maria Cristina da Silva. O Urbanismo No Brasil. São Paulo: Studio Nobel; FAUUSP; FUPAM, 1999.

MAGNANI, José G. C. Rua, símbolo e suporte da experiência urbana. 2000b. Disponível em <http://nau.fflch.usp.br/sites/nau.fflch.usp.br/files/upload/paginas/rua_simbolo\% 20 e\%20suporte\%20da\%20experiencia\%20-\%20magnani.pdf $>$. Acesso em: 20 agosto. 2016

MARKOVÁ, Ivana. Le focus groups. Em S. Moscovici \& F. Buschini (Orgs.), Les méthodes des sciences (pp.221-242). Paris: Presses Universitaires de France.

PRODANOV, C E FREITAS, E (2013). Metodologia do Trabalho Científico: Métodos e Técnicas da Pesquisa e do Trabalho Acadêmico. Rio Grande do Sul. Feevale.

RIO, João. A Alma Encantadora das Ruas. Martin Claret. São Paulo. 1908.

SCHARF Edson, Análise Da Propaganda De Automóveis No Brasil: A Campanha Publicitária De Lançamento Do Citroën C3 Picasso A Partir De Puto E Wells. Rio de Janeiro, 2013.

SHOUP, Donald. The High Cost of Free Parking. Chicago: Planners, 2004. 
Simmel, G. - A Metrópole e a vida mental. In Velho, O. G.(cord.), O Fenômeno Urbano. Rio de Janeiro, Ed. Guanabara, 1987.

SPECK, Jeff. Cidade Caminhável. Perspectiva. São Paulo. 2012.

\section{ANEXO I}

\section{Questionário}

1. Qual o sexo?

Masculino $\quad \square \quad$ Feminino

2. Faixa etária:

$\begin{array}{lll}\text { Menos de } 18 & \quad \text { Entre } 18 \text { e } 25 \quad \square \quad \text { Entre } 26 \text { e } 30 \quad \square \quad \text { Entre } 31 \text { e } 40 \quad \square \quad \text { Entre } 41 \text { e } 50 \\ \text { Entre } 51 \text { e } 60 \quad \square \quad \text { Acima de } 60 & \end{array}$

3. Onde você mora? (Olhar plaquinhas) $\mathrm{N}^{\circ}$

4. O que você faz no CEUB?
Estudo
Trabalho
Estudo e trabalho

5. Qual o seu turno?
Matutino
Vespertino
Noturno
Integral

6. Qual o seu curso? (Olhar plaquinhas) $\mathrm{N}^{\circ}$

7. Você faz outra atividade (intelectual) fora do CEUB?

Não

Cursinho

Curso Para Concurso Público

Outra Faculdade

Estágio

Trabalho

Outros:

8. Qual ou quais meio (s) de transporte você usa para ir ao CEUB?

Carro $\square$ Ônibus $\square$ Metrô $\square$ A pé $\quad \square$ Bicicleta $\square$ Lotação $\square$ Carona
Uber $\square$ Táxi $\square$ Motocicleta: $\square$ Van escolar $\quad \square$ Outros:


9. Quanto tempo você passa no CEUB?
Apenas a manhã
Apenas a tarde
Apenas a noite
Manhã e tarde
Tarde e Noite
Manhã e Noite
O dia todo

10. Quantas refeições e/ou lanches você faz no CEUB?
Nenhuma
2
3
Mais de 3

11. Que espaços dentro do CEUB vocês utilizam para interagir, conversar com os amigos, lanchar ou passar os intervalos?

\begin{tabular}{|c|c|c|c|c|c|c|}
\hline Píer & Bosque & $\square \quad$ Biblioteca & $\square$ & Bloco/Salas & $\square$ & Praça do Bloco $\subseteq$ \\
\hline Fumódromo & Arquiba & da do bloco 8 & $\Pi$ & Quadras & $\square$ & CA do curso \\
\hline Áreas abertas & $\square \quad$ Áre & alimentação & & DCE & $\square$ & Baião \\
\hline
\end{tabular}

Outros:

12. Você acha que as áreas abertas internas de convivência do CEUB atendem à demanda?

$$
\text { Sim } \square \quad \text { Não }
$$

13. Você sente falta de melhores espaços para descansar, conversar e interagir com outras pessoas dentro do CEUB?
Sim
Não
Indiferente

14. Você acha que os espaços abertos internos do CEUB possibilitam:

( ) Maior segurança social

( )Maior integração da pessoa com a faculdade

( ) Criação de amizade com pessoas de cursos diferentes
( ) Isolamento de algumas pessoas

( ) Sensação de descanso mesmo durante a jornada de atividades

( ) Sentimento de acolhimento

15. Você acha que os estacionamentos internos do campus interrompem o deslocamento entre os blocos?

$$
\text { ( ) Sim ( ) Não }
$$

16. Você acha que seria interessante criar espaços de convivência para todos, no lugar dos estacionamentos privativos para professores, como, 0 
estacionamento em frente ao bloco 3 e no estacionamento entre o bloco $1 \mathrm{e}$ o bloco 2? (Ver plaquinha).

\section{( ) $\operatorname{Sim}($ ) Não}

17. Você acha que lugares abertos, com arborização e espaços para relaxar iriam melhorar o desempenho dos alunos? Por que?

( ) $\operatorname{Sim}($ ) Não

R: 